\title{
The Emergence of the Corporate Form
}

\author{
Giuseppe Dari-Mattiacci \\ University of Amsterdam
}

Oscar Gelderblom

Utrecht University

Joost Jonker

Utrecht University and University of Amsterdam

Enrico C. Perotti

University of Amsterdam and CEPR

We describe how, during the 17th century, the business corporation gradually emerged in response to the need to lock in long-term capital to profit from trade opportunities with Asia. Since contractual commitments to lock in capital were not fully enforceable in partnerships, this evolution required a legal innovation, essentially granting the corporation a property right over capital. Locked-in capital exposed investors to a significant loss of control, and could only emerge where and when political institutions limited the risk of expropriation. The Dutch East India Company (VOC, chartered in 1602) benefited from the restrained executive power of the Dutch Republic and was the first business corporation with permanent capital. The English East India Company (EIC, chartered in 1600) kept the traditional cycle of liquidation and refinancing until, in 1657 ,

Giuseppe Dari-Mattiacci gratefully acknowledges the financial support by the Netherland Organization for Scientific Research (NWO VIDI grant 016.075.332) and the Becker-Friedman Institute at the University of Chicago (BFI Fellowship winter 2012). The authors would like to thank Kenneth Ayotte, Douglas Baird, Patrick Bolton, Boudewijn Bouckaert, David le Bris, Tony Casey, Christoph Engel, Andreas Fleckner, Luis Garicano, William Goetzmann, Jeff Gordon, Henry Hansmann, Ron Harris, Martin Hellwig, Dick Helmholtz, Egbert Koops, Jonathan Macey, Elias Papaioannou, Martijn Punt, Ailsa Röell, Roberta Romano, Tano Santos, Richard Squire, Oren Sussman, Eric Talley, Joeri Vananroye, Barry Weingast, Mark Weinstein, and the participants in seminars at Max Plank Institute for Collective Goods in Bonn, Oxford University, the University of Amsterdam, the European University Institute, Paris X University, and Yale Law School, the annual meeting of the Italian Society of Law and Economics (University of Rome 3, 2012), the annual meeting of the American Law and Economic Association (Vanderbilt University, 2013), the ACLE Spring Workshop on "Endogenous institutions" (University of Amsterdam, 2013), the TILEC Workshop on "Economic governance and organizations" (Tilburg University, 2013), the CEPR European Summer Symposium in Economic Theory (Gernzensee, 2014) and the Dieter Heremans Fund Lecture (KU Leuven 2015) for helpful comments and suggestions.

The Journal of Law, Economics, and Organization, Vol. 33, No. 2

doi:10.1093/jleo/ewx002

Advance Access published March 24, 2017

(C) The Author 2017. Published by Oxford University Press on behalf of Yale University.

All rights reserved. For Permissions, please email: journals.permissions@oup.com Downloaded from https://academic.oup.com/jleo/article-abstract/33/2/193/3089484 
the English Civil War put the crown under strong parliamentary control. We show how the time advantage in the organizational form had a profound effect on the ability of the two companies to make long-term investments and consequently on their relative performance, ensuring a Dutch head start in Asian trade that persisted for two centuries. We also show how other features of the corporate form emerged progressively once the capital became permanent. (JEL: G30, K22, N24).

\section{Introduction}

The world's biggest and most powerful firms are corporations. A corporation is a firm with special legal attributes that make it capable of owning property, entering into contracts, and standing in court independently of its owners. The corporate form was originally established for public bodies and public utilities, such as a municipality or a monastery. We focus here on the emergence of business corporations; from a legal theory perspective, we show how a public law notion migrated to private law.

The corporation has long been regarded as a nexus of contracts, with corporate law as a menu of default contractual arrangements (Jensen and Meckling 1976: 310-11; Easterbrook and Fischel 1991). This approach gives the law an accessory role, neglecting the "significance of the allocation of property rights to [productive] assets for the governance of the enterprise" (Armour and Whincop 2007: 431).

The economic theory of the firm (Grossman and Hart 1986; Hart and Moore 1990) recognizes ownership as a way to allocate residual control rights over firm assets. Still, it does not explain whether these assets should be owned by real persons or by a fictitious legal person, i.e. the corporation. This leaves open some important questions. What is the role of the law in providing a firm with corporate status, and why could private contracts not replicate that? How exactly did the legal innovations necessary for the corporate form emerge?

The recent theory of legal entities (Hansmann and Kraakman 2000a; Hansmann et al. 2006) has clarified that the law is essential in providing the corporation with distinct property rights and, in particular, a dedicated pool of assets shielded from the shareholders' personal creditors. Importantly for our analysis, corporate assets are shielded also from the owners: by joining a corporation investors wave the right to unilaterally withdraw their capital. ${ }^{1}$ Through the corporate form the law provides a way for investors to commit capital for the long term, often indefinitely, to

1. Note that the sale of shares does not amount to a withdrawal, since the capital remains locked in the corporation, only the identity of one of the owners change. As Hansmann et al. (2006: 1338) clarify, withdrawal from a corporation is only possible following a decision by a majority or supermajority of the shareholders. 
a business venture. Partnerships do not offer the same level of commitment (see Blair 2003). ${ }^{2}$

In this article, we explain the historical emergence of the permanent commitment of capital, a critical step in the emergence of the corporate form that also creates agency problems in corporate governance. Traditionally, individual investors could control their investment by their right to withdraw at will, limiting the discretion of active partners. This right had to be surrendered in order for the firm to pursue a longterm strategy and grow to its modern scale (on the link between long-term investment and lock-in see also Lamoreaux and Rosenthal 2006).

Historically, production and trade did not require much long-term investment. A partnership of family and friends could supply enough capital. The Florentine banking businesses of the 14th and 15th century were run by families, such as the Bardi, the Peruzzi and the Medici (Hunt and Murray 1999). However, the onset of the long-distance trade during the 16 th and 17 th century demanded an escalation in size and risk-bearing capacity, requiring capital from many investors beyond the safety of familiar circles. This created a twin problem: how to establish a long-term capital commitment in the business, and how to control the risk of its expropriation, both private and public.

Traditional Roman partnership law adhered strictly to the principle of exit at will, which gave each individual partner the right to force the liquidation of the partnership. This principle prevented parties from credibly agreeing to remain in a partnership for the long term: lock-in contracts were not fully enforceable in court. Overcoming this limitation required a legal innovation, not merely a contractual one. Only the law could grant capital permanence to private corporations, extending a privilege until then enjoyed by public corporations such as townships, monasteries, and hospitals.

Capital lock-in, however, exposes owners to new risks associated with a permanent loss of control. The risk of private expropriation introduced the modern corporate governance problem, related to managerial accountability. Yet public expropriation was at the time a greater risk, as most European countries were ruled by absolute monarchs. Private owners were understandably reluctant to lock in capital to invest in assets such as ships and forts that could be diverted to military purposes, or exposed to the loss of monopoly rights. Our conclusion is that we observe the emergence of the corporate form only where and when the risk of public expropriation was relatively low due to a country's suitable political institutions. Indeed, in the most autocratic countries (such as Spain or Portugal), colonial trade was organized as a royal monopoly.

2. Under current American law, for instance, the commitment not to withdraw capital from a partnership is enforceable only if it is stipulated for a limited period of time (Hansmann et al. 2006: 1393). See also Stout (2005) and Schwartz (2012) for further analyses of the implications of lock-in. 
The historical evidence on the chartering of the Dutch East India Company, the Vereenigde Oost-Indische Compagnie (VOC), in 1602 in Amsterdam, supports this interpretation. England chartered its East India Company (EIC) two years earlier, in 1600. Both companies were motivated by the prospects of high gains from trade with Asia. Newly discovered intercontinental routes pioneered by the Portuguese made it possible to bypass the middlemen operating along the land routes to the Far East that had been used for centuries. The prospective gains were unprecedented. At the same time, the need to establish a safe route against competing powers required exceptional investments and risk bearing capacity.

The two companies started with comparable capital but differed in an important dimension: the VOC charter adopted a longer maturity for its equity. This induced immediately another innovation, namely the free transferability of shares to ensure liquidity for the locked-in capital. The degree of capital commitment was made permanent within a decade, at a critical juncture in the competition with the English company. The VOC could thus outspend and outperform the EIC for decades. Though the EIC board sought to emulate the Dutch, it succeeded only half a century later, enough for the Dutch to pull ahead and seize the prize location for the spice trade (Gaastra 2007). Figure 1 illustrates the dominance of the Dutch graphically: they sent more ships to Asia than all other European countries taken together. England, its closest competitor, totaled less than half of the Dutch and started to close the gap only in the second half of the century.

Capital lock-in broke dramatically with prior commercial practice and the reigning traditional Roman law principles of exit at will. The first Dutch and English voyages to Asia were organized as separate, individual expeditions, investors committing their capital for one trip at a time. The dissolution of the partnership upon return of the ships ensured a clear division of the profits among partners, upon which a new partnership could be established. The English EIC remained subject to this constraint much longer, until the middle of the 17th century (Figure 2).

The different maturity of equity in the VOC and the EIC resulted in measurable differences in their investment strategies in Asia. In particular, the VOC rapidly built and maintained a large permanent Asian fleet and invested heavily in forts and warehouses in Asia to establish trade routes within Asia, overcoming the Portuguese and English competitors (Parthesius 2010; Knaap et al. 2015). In stark contrast, the EIC kept a much smaller permanent Asian contingent (Figure 3). ${ }^{3}$ Having a specialized Asian fleet and a separate trading fleet allowed the VOC to operate

3. On the debate on the efficiency of the organizational model adopted by the early trading companies of the 17th century see Jones and Ville (1996a and 1996b) and Carlos and Nicholas (1996). 
Ships sent to Asia from Europe

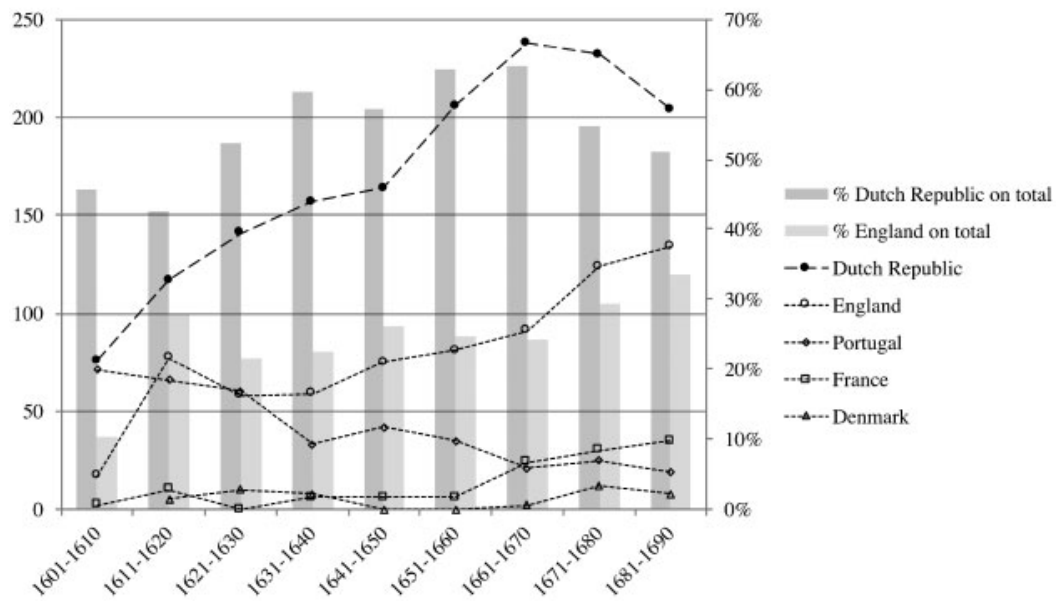

Figure 1. The number of Ships sent from Europe to Asia, 1600-1690.

Source: De Vries (2003).

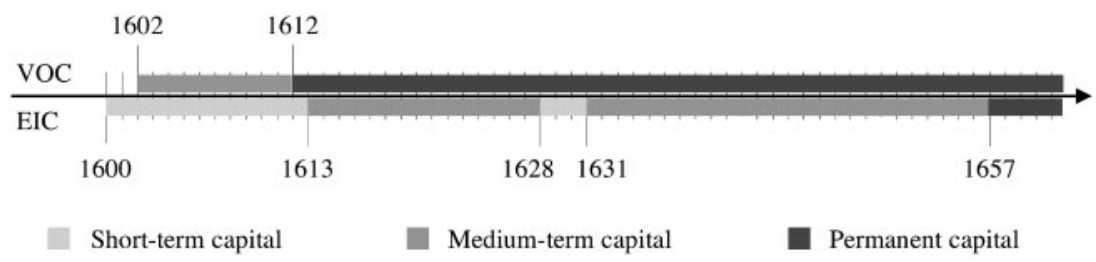

Figure 2. Capital Structure of the VOC and the EIC.

Asian fleet

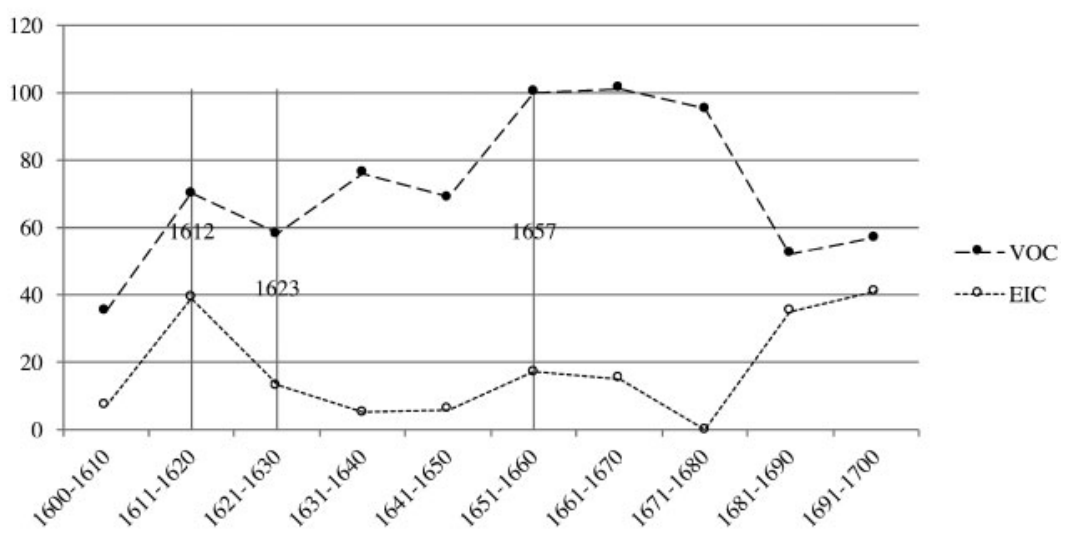

Figure 3. The Number of Ships in the Asian Fleet 1600-1700.

Source: van Dam (1927); Chaudhuri (1965; 1993); Bruijn et al. (1979-1987); Steensgaard (1982). 
faster return voyages between Europe and Asia (see below, Figure 12), which contributed to its dominance.

The English had soon come to admire the Dutch model of locked-in capital and reinvestment of earnings: ${ }^{4}$

"[I]t was the policy and wisdom of the Hollanders by this way to advance the small stock which they raised at first to that greatness which now it is, by forbearing divisions, which course, if this Company observe, [the Governor] doubted not to improve it for the good of the Company." (Court Book, XIV, 354, 20 June 1634) ${ }^{5}$

Indeed, the EIC took the VOC as a role model for commerce, empire building, fortifications, and the use of religion in governing the Asian territories until the VOC's decline in the late 18th century. Yet, the EIC failed to introduce capital lock-in until 1657 (Chaudhuri 1965: 223; Harris 2005a: 45). Why? Demsetz (1967) and North (1990) view institutional change as a convergence of strong interests to take advantage of an economic opportunity. The Portuguese and Spanish monarchies were the first movers, establishing colonial trade under a royal charter, but in the early 1600s several European countries (France, Britain, the Netherlands, Sweden, Denmark) moved to grant monopoly rights to trade companies. So why did the corporate form arise first in the Dutch Republic, and was not adopted elsewhere for decades?

The reason was the peculiar political economy of the Dutch Republic. In 1581, the Low Countries had abjured their Habsburg ruler and subsequently established themselves as a republic with a federal structure and a limited central power responsive to commercial interests. Since the risk of expropriation by the government in the Dutch Republic was low, traders were willing to commit their capital for the long term. In contrast, during the first half of the 17 th century, the English crown operated dictatorially and largely free of parliamentary control. It was only following the Civil War (1642-1648) that the power of the English crown with respect to war and taxation was significantly limited. Consistently with this view, in 1657 the new EIC charter provided the company with permanent capital. The Glorious Revolution (1688) cemented these political changes.

This article is organized as follows. In Section 2, we examine the legal components of the corporate form. We single out the legal innovations that took place before the chartering of the VOC in 1602: the principle of representation, weak entity shielding, limitedly tradable shares, and limited liability for passive shareholders. In Section 3, we show that capital lock-in was a crucial turning point in the process of development of the

4. For the EIC, the VOC was a role model for commerce, empire building, fortifications, and the use of religion in governing the Asian territories until the decline of the VOC in the 18th century (Stern 2011: 49, 60, 63, 72, 80, 86, 89, 94, 102, 103, 114, 117, 122, 128, 197).

5. Cited in Chaudhury (1965: 222). 
modern features of the corporation. The 1602 VOC charter established a medium-term capital lock-in, which was enough to trigger immediately strong entity shielding and full tradability of shares. In 1612 this commitment became permanent. Full limited liability of managing shareholders was added only in 1623. Importantly, this change occurred by contractual choice - as there was no explicit statutory intervention - although it was later upheld in court. In Section 4, we identify the political economy determinants of this process by comparison with the EIC. We face serious limitations in the data, as explained in the Appendix. Nevertheless, the available data tell a compelling story about the more solid capital foundations of the VOC, its ability to invest for the long term and, consequently, its larger gains. In Section 5, we conclude. The Appendix also contains additional graphs and data analysis.

\section{The Components of the Corporate Form}

\subsection{Essential Features}

The corporate form is a set of features that enable a company to have an autonomous life independent of its investors (Macey 1999; Blair 2003 and 2013; Armour et al. 2009: 5-15), that is, to operate as a distinct legal person:

1. Representation (agency) enables a principal to give an agent authority to enter into contracts in his name so that, for example, if the agent purchases a good from a seller, the property of the good and the liability for the payment of the price accrue directly to the principal rather than to the agent.

2. Entity shielding protects company assets from the personal creditors of the owners. Absent entity shielding, company assets are just a jointly owned pool of assets and hence can be freely seized by personal creditors. Weak entity shielding only gives company creditors priority over personal creditors on company assets, while strong entity shielding also prevents personal creditors from liquidating the company. Importantly, strong entity shielding also prevents individual owners from withdrawing their capital and forcing the liquidation of the company. ${ }^{6}$

3. Capital lock-in allows the company to retain its capital for the long term. Absent lock-in, exit from a company is at will and hence each of the partners can force the liquidation of the business.

4. Tradable shares enable individual owners to exit without withdrawing any capital. Critically, ownership can be transferred without shareholder approval.

6. A third form of entity shielding, complete entity shielding, places company assets entirely out of the reach of personal creditors (Hansmann et al. 2006). It is a typical form for trusts and non-profit corporations and hence not relevant for our analysis. 
5. Limited liability shields the owners' personal assets from company creditors.

Representation, while introducing some potential problems - the agent might for instance misrepresent the scope of his authority to a third party - makes business more expedient, especially when the principal is a company rather than an individual.

Entity shielding and limited liability partition assets in two distinct sets: company assets and personal assets of individual owners. Limited liability protects the personal assets of the owners from company creditors. By contrast, entity shielding protects company assets from personal creditors of the owners. Restricting claims on company assets (entity shielding) has been shown to be more important than restricting claims on the owners' personal assets (limited liability) because it has a greater impact on the ability of the company to borrow and continue operating. While weak entity shielding only gives company creditors priority over personal creditors on company assets, strong entity shielding adds a rule of liquidation protection that extends to owners. Yet, liquidation protection is effective only as long as the owners' commitment to keep their capital locked in the company is enforceable. When this commitment expires, the company loses strong entity shielding; then, the owners and their personal creditors can force the liquidation of the company. ${ }^{7}$ Entity shielding is a property right, which requires the law and cannot be easily mimicked by contractual arrangements (Hansmann and Kraakman 2000a; 2000b).

We advance two notions here. First, the investors' ability to commit capital for the long term can be seen as a corporation's right to retain its capital. Second, the establishment of lock-in calls for the development of additional features. A direct implication of lock-in is liquidation protection against owners and their personal creditors (strong entity shielding). Moreover, a consequence of capital lock-in is a major loss of liquidity, which calls for the establishment of a liquid market for shares so individual investors can exit. The establishment of capital lock-in was the catalyst for the simultaneous development of both strong entity shielding against personal creditors (a necessary legal implication) and tradability of shares (an economic necessity).

Interestingly, limited liability is a right that belongs to the shareholders rather than the company itself. Accordingly, it appears as a less essential ingredient of the corporate form, as it can be created by the parties through appropriate contractual arrangements. Admittedly, limiting tort liability by contract is more complex, but the explosion of tort claims is a very recent phenomenon (Hansmann et al. 2006: 1341 fn. 15).

7. Hansmann et al. (2006: 1338; 1349 fn. 39) show that liquidation protection against owners, although conceptually distinct, is usually paired with liquidation protection against creditors. 


\subsection{Historical Developments Prior to 1602}

Under the traditional Roman laws of agency and partnership, a company was simply a private contract among individuals (societas) to share losses and gains. It did not affect third parties. Any change in the partners' identity would end the old contract and require a new one to continue operations (no tradable shares). Partners were personally liable for company debts (no limited liability), personal creditors of the partners could seize company assets (no entity shielding), and the partners could rely neither on agents nor on each other to commit the company (no representation) (Abatino et al. 2011; Hansmann et al. forthcoming).

Possibly, the most important limitation imposed by Roman law principles was the lack of legal means to commit capital for the long term, as participation was essentially at-will both for partners and for co-owners (no capital lock-in; Arangio-Ruiz 1993: 231, 350; Fleckner forthcoming). While it was possible to contract a commitment for a specified term, such agreements were only enforceable through damages; the dissolution of the partnership was inevitable whenever one of the partners decided to withdraw. Damages were not due if the partner forcing liquidation had a just cause, which was broadly construed as to include simple disagreements with other partners. Damages were meant to discourage fraudulent behavior. Moreover, these contracts were only valid among the partners and did not bind creditors or heirs. Owning property in common did not help as co-ownerships were essentially subject to the same rules. ${ }^{8}$ By giving each partner a veto power on the continuation of the company, the principle of exit at will limited agency costs, but curbed the lifespan of the business and exposed it to inefficient early liquidation.

In sum, although the Roman law recognized the corporate status of some public bodies, ${ }^{9}$ private companies had no rights or assets of their own and did not exist as separate legal entities. For a brief period of time, these limitations were lifted for public contractors (societates publicanorum; Malmendier 2009; Fleckner 2010), which, however, disappeared long before the fall of the Western Roman Empire and did not serve as a blueprint for medieval business. ${ }^{10}$

New rules supporting private enterprise evolved during the Middle Ages. Weak entity shielding developed relatively early; Hansmann et al. (2006: 1366-67, 1375-77) show that it was already a characteristic of the Italian compagnia in the 13th century and an established principle in the

8. The Digest of Justinian (Watson 2009) contains several texts clarifying these issues; see, for instance, D. 17.2.1.pr, D. 17.2.4.1, D. 17.2.14, D. 17.2.65.3-8, and D. 17.2.70.

9. See the Digest of Justinian (Watson 2009) at D. $3.4 .1 \mathrm{pr}$.

10. Some of these limitations were bypassed by using slaves as business agents (Abatino et al. 2011); however, also this solution disappeared before the fall of the Western Roman Empire. Zimmerman (1996: 38-39; 184-6) illustrates some methods to evade the restrictions on representation in classical Rome and discusses the fenus nauticum, a loan contract for maritime trade that conditioned repayment of the load to the return of the ship. Effectively, the creditor took a position similar to a passive partner in a limited partnership. 
Dutch Republic by the time of the VOC. ${ }^{11}$ Agency law (representation) followed a similar pattern. The glossators of the 12 th century cast doubts on the validity of the Roman principle of alteri stipulari nemo potest (no representation). Exceptions had been carved out in canon law and existed in the $16 \mathrm{th}^{\text {th }}$-century natural law. By the time of the VOC, commercial practice had long accepted the principle of representation and partners were treated as jointly and severally liable to third parties for transactions carried out within the scope of a partnership. Yet, the principle was not completely established until the 17th century. Legal scholars and, to a more limited extent, the Dutch Supreme Court continued to follow Roman law principles (De Ruysscher 2016; Punt 2010: 283-86). In legal scholarship, the change was pioneered by the Dutch Hugo Grotius in 1625, who supported representation in his De iure belli ac pacis, in response to the needs of the Dutch trading economy ahead of other European countries (Zimmerman 1996: 41-44).

Limited liability followed a more complex and lengthy evolutionary path. In the 10th and 11 th century, Italian merchants were already experimenting with a form of limited partnership. In the commenda-which was similar to an earlier Islamic institution, the qirad - and in its successor, the societá in accomandita, passive partners were only limitedly liable to the extent of their investment; their personal assets were not at stake (Favali 2004; Mignone 2005). In contrast, managing partners remained personally liable until the 17th century (Montanari 1990).

The evolution of limited liability betrays a resilient principle of Roman law: business was a personal endeavor and it was crucial that businessmen bore both commoda (gains) and incommoda (losses) deriving from business activities. The same principle also stood in the way of mechanisms to trade one's position in a partnership. ${ }^{12}$ It is not surprising that the short-term investments typical of partnerships without locked-in capital did not create liquidity concerns and hence did not generate a demand for transferability.

However, at the end of the 16th century, the onset of the Asian trade radically increased the distance traveled by commercial fleets and the duration of the voyages, which took about two years to complete. It also increased the cost per ship from 25,000 to 100,000 guilders and multiplied the risks involved. The need to collect capital from a much larger base and the natural lock-in of the capital until the return of the ships made it necessary for the partnerships that preceded the VOC to provide for share transferability in the contract, albeit with some limitations. Yet,

11. The recorded customs of Antwerp are evidence that weak entity shielding was recognized by the time trade moved from Antwerp to Amsterdam at the end of the 16th century due to the Spanish occupation of the city (De Ruysscher 2016). Punt $(2010$ : 158-59,282) shows that the Dutch Supreme Court recognized weak entity shielding generally for partnerships in the 18th century. Hansmann et al. (2006: 1376-77, 1380-81) also find traces of entity shielding in a 1683 English case.

12. See Abatino et al. (2011) for a discussion of transferability in Roman law. 
allowing partners to trade shares did not establish a liquid market. Transfers occurred only rarely, mainly following bankruptcy or death of a partner (Gelderblom and Jonker 2004: 648-49, 653-55). Tradability per se only preserved the continuity of the business venture in the face of adverse events, essentially protecting the interests of the solvent or surviving partners by avoiding the dissolution of the partnership.

Creating a liquid market required certainly a significant mass of investors, but what proved critical was the development of an official company share register that served to notify, standardize and streamline share transfers (see Section 3.2.3). Combined with the enhanced liquidity needs arising during a long equity maturity, this ensured significant demand and supply.

While weak entity shielding, representation, limited liability for passive partners, and limitedly tradable shares had been introduced by the time of the VOC, capital lock-in, full tradability of shares and, finally, general limited liability for managing partners appeared in stages within 20 years after the chartering of the VOC. A rare exception emerged in Toulouse, where grain mills had limited liability for shareholders and directors, and tradable shares since at least the 14th century (Sicard 1953; Goetzmann et al. 2015). ${ }^{13}$ Yet, this model was not extended to large, risky commercial operation and remained limited to supplying the infrastructure for natural public services. The assets were immovable and yielded a fairly stable income on an annual base, receiving a fixed fraction of the wheat milled. While the mills were indeed private property, functionally, they were a public utility. The VOC's original corporate form also owed much to it having been modeled on existing public utility bodies in the Dutch Republic such as admiralties (Gelderblom et al. 2011a).

\section{Legal Innovations in the VOC}

3.1 Organizational Law Prior to the VOC

Before the chartering of the VOC, private partnerships in the Low Countries were short-term, unlimited-liability endeavors. This was not seen as a limitation, as few businesses required large capital investments; most of the value added was due to labor. Sole proprietorship was the dominant business form in agriculture (De Vries 1974; Bieleman 1992: 31100; van Bavel and Gelderblom 2009). Manufacturing was dominated by urban craftsmen who worked in small workshops. Only the most capitalintensive production units, like sugar refineries and breweries, were sometimes owned by general or special-purpose partnerships (Yntema 1992; Poelwijk 2003; de Jong et al. 2013).

13. The mills of Toulouse derived their organization form from the feudal institution of pariage (proportional ownership), which developed out of the need to guarantee the unity of inheritances while preserving an equal treatment of the heirs (Goetzmann and Pouget 2011). 
General partnerships were also the principal vehicle for international trade. Following Roman law, partnerships could be formed for a term but the agreements could be enforced only through damages - which were not due if there was a just cause - and did not bind heirs (Punt 2010: 134-43). Trade expeditions were normally financed for single voyages, with default liquidation upon the ships' return (Gelderblom and Jonker 2004; Gelderblom et al. 2011b). This format entailed a measure of "natural" capital lock-in because, while the fleet was away, liquidation was materially impossible until its return. Upon its return, the accounts were more or less literally settled on the quayside, partners inspecting the cargo and dividing the profits. While this structure did not encourage investment in long-term assets which would have been hard to value or liquidate, it ensured minimal agency costs, as active partners had limited time and scope for discretionary decisions. The lock-in introduced by the 1602 VOC charter implied a radically different sort of commitment, fully backed by the law.

Limited liability for active partners was similarly absent. In the Dutch Republic, the only entities enjoying limited liability for active managers were public entities, such as water-management bodies (van Tielhof 2009: 215-20), municipalities, religious institutions, charities, guilds, universities, and, from the 1580s onwards, admiralties (Rijpma 2012: 28-32). The corporate form extended to selected private entities with a public function, such as land reclamation projects - copen and polderbesturen-which required an indefinite life and were organized similarly to water management bodies. ${ }^{14}$

It is important to stress that the VOC charter was not a private contract among traders but rather a legislative act and that the legal innovations contained therein did not extend to other companies. Throughout the 18 th century, the Dutch Supreme Court continued to treat partnerships as inherently based on continued unanimous consent. As a result, agreements to lock in capital for a certain period, make shares fully tradable or limit the partners' personal liability remained difficult to enforce (Punt 2010: 279, 282, 283). ${ }^{15}$ Since contractual solutions were not readily available, the VOC had to break with long-lasting principles by force of legislation. The government obliged because, along with commercial interests, the VOC also served a public purpose, as it pooled resources to contribute to the

14. From the year 1000 onwards Dutch peatlands were drained using so-called cope contracts, long-term leases that gave the occupants extensive land-use rights (van der Linden 1955 ) and the right to transfer them to others without approval (though land ownership remained in the hands of the feudal lord). Land reclamations in the 16th and 17th centuries were funded by private special-purpose partnerships. Once land reclamation had been completed, the initial partners could no longer be asked to subscribe additional capital. Landowners were free to sell their landholdings (van Zwet 2009: 51-83). On England see Harris (2005b: 220-23).

15. Even limited liability for passive partners, while enforced in merchant courts, remained highly controversial in scholarship and in public opinion (Kessler 2003). 
military advancement of Dutch interests overseas. But due to its commercial goals, the VOC was not conceived as a public contractor, like the societates publicanorum in Rome nor as a public utility company, like the mills of Toulouse. Its private law notion of corporate entity gradually broke free from its public law origins.

\subsection{The Coalescence of the Corporate form in the VOC}

Until the end of the 16th century, Spain and Portugal dominated European trade with Africa, Asia, and America. This changed when in 1581 the Dutch abjured the Spanish King Philip II and declared their independence from the Habsburg Empire. In 1585, the city of Antwerp, which had been part of the revolt, fell again into the hands of the Spanish, but the Dutch rebels continued to control the river Scheldt and the Flemish coast, cutting access to Antwerp's harbor. The city, a major commercial hub, could no longer function as a gateway to northern Europe, as a result of which many foreign and local merchants moved their business elsewhere. The Flemish merchants who had begun trading with Russia, Africa, and the Levant in Antwerp in the 1560s and 1570s chose to settle in Middelburg or Amsterdam. They brought with them their commercial customs, which, as we have emphasized above, were more advanced than the traditional principles still embraced by legal scholars and, to a more limited extent, courts. Crucially, these customs championed the principles of representation and weak entity shielding. It was not long before merchants from Zeeland and Holland joined their efforts to establish an independent presence in markets outside Europe.

3.2.1 Single Voyages, 1590-1600. The first expeditions sailing from the Dutch Republic to Asia during the 1590s adopted tried and tested funding strategies. The typical contract was a general partnership with some additional features. The promoters drafted contracts for single trips, but with more than one ship, a longer time horizon, due to a longer duration of the return voyage, and a larger number of shareholders than common before. The initiators invested their money under the same conditions as all the other shareholders but, in exchange for a commission fee, they planned the expedition, instructed and monitored shipmasters and trading agents, and handled the return cargoes. Piecemeal dividend payments were made as sales progressed and once the companies had sold out, accounts were drawn up and the partnership was liquidated. Investors in these expeditions had the option, but never an obligation, to reinvest in a subsequent one. These first expeditions to Asia followed the rules of traditional partnerships. All investors were jointly and severally liable for any debts incurred by the initiators, but their liability was effectively limited in two ways. First, the investors could deny any claim that followed from actions that lay outside the designated purpose and duration of the partnership. Second, they could invoke maritime law and abandon their investment in case of total loss of the ship due to shipwreck or capture, a 
provision common in shipping ventures (Gelderblom and Jonker 2004; Gelderblom et al. 2011b).

In 1597 the first three ships returned from Asia. Although their cargo hardly covered the expedition's costs, this failed to dent the belief that large profits could be made, resulting in a wave of new trips organized by merchants from Amsterdam, Middelburg, Veere, and Rotterdam. State coordination remained limited to arrangements with the local and provincial governments about sailing in convoy and the supply of ordnance and ammunition. Setting up a long-term trading company would have yielded higher gains than single-voyage contracts, because the long-term investment would have made it easier to secure the Cape route. However, long-term commitments entailed moral hazard costs, due to the directors' superior information on trading operations, while there always remained the possibility that other Dutch traders would recruit investors to set up a rival company and reap the benefits of this emerging trade.

3.2.2 Local Coordination, 1600-1602. Competition between the various cities led to the dispatch of no less than 62 ships between 1597 and 1601 - a much higher number than in England, where only one group of London merchants had received a royal charter to trade with Asia (De Vries 2003; Gelderblom 2009). As the vast majority of ships returned with rich cargoes, profits were very high. Between 1598 and 1608 the investors in Amsterdam's early companies earned an average annual return of $27 \%$ (Gelderblom 2003). But company directors and government officials realized that competition could undermine profits, while the growing Dutch presence in southeast Asia also rendered Spain increasingly wary, thus raising the likelihood of attacks on shipping to and from the east. These worries inspired the city councils of Amsterdam and Middelburg to apply a device that had been used successfully in Amsterdam's Africa trade in 1598: the merger of local companies. In 1600 the Oude Compagnie and the Nieuwe Compagnie in Amsterdam coordinated their sailing and in 1601 they amalgamated into a new company to send out a fleet of eight ships. A similar attempt in Middelburg failed, however, on the refusal of prominent merchant Balthasar de Moucheron to join.

The failure to unite in Zeeland reveals the inherent instability of coordination at the local level. It might have raised profits in the short term, but the arrangement was prone to opportunistic behavior, if only because the large number of competing ports made it easy enough for traders to invest in another company or even create a new one. Since local coordination did not guarantee large future profits, merchants had no incentive to commit capital for a longer period. Thus, Amsterdam's united company continued to be organized as a special purpose partnership, with a small committee of managing directors drawn from the two previous companies in charge of equipment and sales. As for protection, the directors continued to borrow military hardware from the city and they worked with the local admiralty board to impose a naval command structure on the fleets sailing to Asia. 
3.2.3 The First VOC Charter, 1602-1612. Since local coordination could not secure the Asian routes, provincial and central authorities pushed for coordination at the federal level. After intense negotiations agreement was reached to establish a public monopoly on the Asian trade for 21 years. Operations would be managed by six local chambers, which appointed a central governing board of 17 delegates (the Heeren XVII) to run the overall business. Amsterdam, the biggest chamber, obtained only eight seats on the board so that it could not dictate proceedings. The other five chambers-Middelburg, Enkhuizen, Delft, Hoorn and Rotterdam, in decreasing order of their capital contribution-filled the rest of the seats in proportion to their share in the total (den Heijer 2005).

The 1602 charter offered an adequate time horizon to secure the Cape route. Shareholders committed capital for 10 years. They were to receive a dividend once accumulated profits (gross of re-investment) reached $5 \%$ of capital. In 1612 they were to receive full accounts, and the option to either withdraw their share or to reinvest it into a new 10-year venture. What was not envisioned at the time was the opportunity cost of liquidating assets in 1612.

The government delegated sovereign powers in Asia to the VOC, notably the rights to conclude treaties with foreign powers, to wage war, levy taxes, and operate a formal legal system for judging its employees. In exchange, the Estates General obtained contractual safeguards in the charter that the company would do its bidding. This hybrid structure of a private commercial company with public responsibilities lent the VOC a special corporate status typical of other public bodies in the Dutch Republic (Gelderblom et al. 2011a). Yet, the 1602 charter did not establish the full legal personality of a modern corporation. The company remained a special purpose partnership, with no permanent capital, and the directors remained unlimitedly liable for any debts incurred on behalf of the company, with the exception of wage arrears - all passive investors were instead liable only for the amount they had put in. Company directors were probably willing to take the risk as they planned to fund trade from share installments until 1607, and from sales revenues thereafter. The 6.4 million guilders' capital raised enabled the company to engage in largescale military investment to secure its overseas position, while the monopoly over commerce with Asia prevented traders from free-riding on the security provided in Asia by the VOC.

As investors might find it difficult to commit funds for such a long duration, it was decided to facilitate the free transferability of shares. This innovation was about procedure and notice. ${ }^{16}$ Shares were already transferable in the partnerships trading before the chartering of the VOC, without trade following. An annex to the VOC charter made shares

16. Note that the company register provided notice of share ownership to potential buyers and creditors, a crucial feature of property rights as opposed to simple contractual rights (Hansmann and Kraakman 2002). 
transferable by laying down a precise and transparent procedure for their transfer which, in order to be valid had to be entered by company clerks in a share transfer register kept in the company office (van Dillen 1958). As a result, it became easy not only to determine ownership of VOC shares, but to find out a person's entire share holdings, information unavailable for the earlier partnerships. Trading in VOC shares started immediately after the closing of subscriptions. Next to reducing liquidity, the longer maturity of the capital subscriptions improved the expectation of profit. Since capital subscriptions did not have to be paid immediately, many investors oversubscribed with the intention of selling some of their shares before capital was called in. This encouraged forward trading and contributed to the liquidity of the market (Gelderblom and Jonker 2004; Petram 2011a, 2011b).

While improving share transferability when investment is short-term makes little economic sense, the free transferability of shares is a crucial complement to long-term investment to the point that, if it were absent, collecting capital from a large base would be impossible. ${ }^{17}$ Underscoring this point is the fact that in Amsterdam approximately $2 \%$ of the adult population took part in the initial subscription and that small investments of as little as 150 guilders were not uncommon (Gelderblom and Jonker 2004: 654). However, looking forward, the VOC never collected new equity again. Transferability was crucial to provide the company with its initial capital and to keep it liquid, but it was capital lock-in that guaranteed, as we will see, a successful long-term approach to investment.

The unprecedented managerial discretion granted to the board was a common cause for concern. From the start, shareholders worried about VOC policy, in particular the priority of war over trade and the lack of dividends. Three merchants and directors of the Amsterdam company, which had merged into the VOC, refused to join when the extent of the new company's hostile intentions became clear (van Dillen 1958: 71, 9899). In 1603 Balthasar de Moucheron, who had long resisted before giving up his own successful trade with Asia, resigned as director over a policy disagreement. Two years later, another prominent investor and director, Isaac le Maire, resigned and sought to pursue trade independently. As a result, their former colleagues petitioned the Estates General in 1606 for a ban on director resignations, but they were turned down (Gelderblom et al. 2011a: 47).

This event underscores the resilience of the view that business was a very personal matter, which can be traced back to the Roman law. The directors of the VOC were considered active partners who were personally liable. As long as they were engaged in business transactions for the company, whether the equipment of fleets, loans, or sales, they could not do what passive investors did: exit the company by selling their shares

17. The EIC also had transferable shares, although transferability was initially limited (Harris 2005b: 234). 
(Gelderblom et al. 2013). The reaction of the Estates General to directors' resignations suggests that limited liability is a de facto necessary feature for full share tradability. Passive shareholders were limitedly liable since the beginning and hence their shares could be freely traded. Active shareholders initially were liable for any debt incurred on behalf of the company, which created a problem of strategic exit to avoid liability.

Throughout the first charter and beyond, pressure remained to allow additional private trade with Asia (van Dam 1927: 220-27). In 1609, le Maire complained to the Republic's powerful statesman Johan van Oldenbarnevelt about the unfairness of keeping private business out of trading areas covered by the company's monopoly but never visited by it. ${ }^{18} \mathrm{He}$ sought to found a rival company in France (Bakhuizen van den Brink 1865), and later organized an expedition to circumnavigate South America via a sea-lane not covered by the VOC's monopoly. The ships reached the Indonesian archipelago, only to be impounded by the VOC. Though le Maire ultimately won a prolonged litigation, this experience discouraged further attempts to test the VOC monopoly. ${ }^{19}$

The VOC immediately set out to gain a strong position and supplant the Portuguese as the major buyer in the best spice trade ports. The Dutch easily outspent the English EIC, which funded smaller expeditions backed by short-term capital. By sheer number of ships, manpower mobilized and sums poured into local infrastructure, the VOC soon secured a commanding position in southeast Asia. However, the volume of military investment exceeded expectations, also because of the Estates General's push for an aggressive stand against the Spanish to relieve pressure on the Republic in Europe. The first fleet sent out in 1603 received instructions to turn the incidental skirmishes conducted by the early companies into systematic fighting. This caused considerable damage to the Spanish and Portuguese trade, and the sinking of ships, cargo seizures and conquest of enemy fortresses ultimately served the VOC's commercial interests. By 1612 the Estates General had to concede that the scale of violence had been much larger than the safeguarding of current expeditions would have required. Ships had to serve more than one purpose, crisscrossing the Indonesian archipelago for years before returning laden to the Dutch Republic, resulting in high wages costs per ton of return cargoes.

Within five years of its formation, VOC directors found themselves confronted with pressing financial shortages (Gelderblom et al. 2013). The four fleets sent out between 1603 and 1607 had exhausted the available cash. Wage bills were met by drawing on the revenues set aside from the van Warwijck expedition, the last one formally organized by an early

18. Shareholder rights 400 .

19. In fact, a last attempt was made at the time of the company's charter renewal in 1622 1623. Jan Pietersz Coen called for allowing participation of private business in VOC controlled ports, to build up the intra-Asian trade. He ran into strong opposition from a coalition of company officials in Asia and the Estates General, and failed to convince the board. 
company but partly managed by the VOC. Very little remained for equipping new fleets, causing the number of ships sent out to drop to only four ships during 1608 and 1609. As a result, the company came under fire from its shareholders back home. The price of VOC shares dropped to a low of $132 \%$ of nominal value and merchants, annoyed about the company's failure to pay dividends from a lucrative trade, started lobbying against any charter extension and in favor of opening access to charter areas not yet developed but now made safe by the VOC's actions. In addition, le Maire launched a massive bear raid on VOC shares in an unsuccessful attempt to force the board to change strategy (van Dillen 1930). The 1609 truce with Spain (1609) changed very little, as it was agreed that breaches outside of Europe would not amount to a violation.

3.2.4 The Transition to Permanent Capital in 1612. As early as 1606 the VOC directors realized the difficulties of liquidating in 1612 and appear to have started lobbying to have that obligation lifted (Robertson and Funnell 2012: 351). Three years later Cornelis Matelieff de Jonge, the commander of the third VOC fleet, spelled out the dangers of the looming liquidation in a memo written at the request of Johan van Oldenbarnevelt. ${ }^{20}$ According to Matelieff, the VOC's position in Asia needed considerable reinforcement, but the 1612 deadline prevented the board from taking the military action required. Any spending now pushed down profits for present shareholders, whereas the benefits would be reaped by investors in the follow-up 10-year account. Yet, Matelieff argued, if no action were taken now, the company would lose ground and it would be very hard to attract investors in 1612. Matelieff added that the decision should not be left to the company directors, because continuing the Asian trade was in the Dutch Republic's national interest. In practical terms, Matelieff suggested that the directors keep their focus on building a strong foothold in Asia and act as if the 1612 deadline did not exist. ${ }^{21}$

Our interpretation echoes Matelieff's view. The statutory expiration of the VOC equity handicapped a long-term strategy, in a race in which commercial and military investment had to be frontloaded. Shortly after Matelieff's report the Estates General awarded the VOC a rebate of 100,000 guilders on customs duties, agreeing that they had pushed the company into war. ${ }^{22}$ In 1610 directors asked for a substantially higher subsidy. Calling itself "a servant of your policies", the board argued that the Asian trade was not a private enterprise but rather an affair of state. As ships and crew were often devoted to war rather than trade, the company could not pay cash dividends to shareholders and had had to raise

20. Haak and Veenendaal (1962: 319-27).

21. Haak and Veenendaal (1962: 324-25).

22. NA 1.04.02 VOC No. 368, resolutions 22 August, 29 September 1609. 
large amounts of debt. ${ }^{23}$ The board also lobbied for the lifting of the charter's requirement to liquidate in $1612 .^{24}$

In March 1612 the directors' formally requested the Estates General to lift the obligation to liquidate, ${ }^{25}$ which, technically, was a clear violation of private shareholder rights. The board presented two sets of arguments, economic ones and political ones. The business case focused on the nature of the VOC's assets. Transferring the complex lot of forts, warships, offices, and debts due in soldiers' pay and merchants' salaries would be extremely difficult. Moreover, presenting the accounts would show the VOC's weak cash position and a successor company would find it difficult to attract investors. The business really needed a permanent basis to keep investing, and more time would permit to reap the benefits. Suspending liquidation would not harm shareholders, as they could sell their shares. Turning to political arguments, the board emphasized the importance of a permanent company as a trustworthy ally for foreign princes. If wound up now, present agreements became worthless, and the uncertainty about its durability would undermine its function as the Estates General's representative overseas. The board professed its willingness to draft accounts for the first 10-year period and subsequently every year in a manner to be set by the Estates General, so as to eliminate any suggestion of opportunism.

At the end of July 1612 the VOC board pressed the Estates for a speedy decision, arguing that competition with the EIC was heating up. Not weighed down by high war costs, the English could undercut the VOC in European sales. Spain and Portugal continued hostilities in Asia despite the 1609 truce. Shareholders threatened litigation to force compliance with the charter. Unless the Estates General provided the subsidy required, started negotiations with the English, and lifted the charter obligations, trade would come to a standstill, pushing up unemployment.

The Estates General considered the matter on Saturday, July 28, 1612, without coming to a decision. On Monday news came from Spain about an imminent offensive on VOC fortresses. The following day, Tuesday, July 31, 1612, the Estates acted. They suspended the charter article concerned, declaring that, "for the benefit, wealth, honor, and reputation of the country, and for other compelling considerations and reasons of state (...) the East India Company should be maintained and conserved in its present state and strength". Decisions on specific points of the company's request were to take another couple of months, but the VOC's capital had become de facto permanent. ${ }^{26}$ For the first time in history, a private firm had gained the prospect of indefinite life.

23. NA 1.04.02 VOC No. 368, resolution 17 November 1610.

24. Resoluties Staten Generaal 1610-1612, 359.

25. NA 1.01 .03 No. 4841, fol 162-167.

26. NA 1.01 .03 No. 4841 fol 181 , July 28,1610 . The actual decision was to lift the obligation to liquidate now, so the resources from the first account could be used to equip the next 
Why did the government intervene? A private solution to ensure continuation would have likely foundered, not least because any individual investor could block continuation. In theory, shareholders could have bought out all those demanding the liquidation of the first account. Yet the price would have been huge, as some traders were eager to make inroads on the VOC monopoly, and in fact any individual shareholder would have held a right to veto the continuation. Had the government not forced a solution, the only legal option would have been to follow the charter, liquidating the first 10-year account and launching a new subscription campaign. But this required the valuation of existing assets, many located in Asia and hard to assess before the return of all ships and the sale of distant property. ${ }^{27}$

\subsubsection{General Limited Liability in 1623. As we have explained, the VOC 1602} charter followed the practice of the time in terms of liability and did not shield active shareholders, the directors, while passive shareholders were limitedly liable. Therefore, rendering the capital permanent in 1612 solved one financial concern of the directors and immediately created a new one. The VOC still needed ready cash to fund its annual fleets, but permanence effectively eliminated the option of raising equity. More equity would have worsened the investors' exposure to the risk of directors' opportunism, and the violation of shareholders' rights would likely have limited their appetite to subscribe. Next to reinvested profits, debt offered a better financing alternative to equity as it could function as a disciplining devise on directors and contain agency costs. As the VOC gradually stepped up its debt exposure, the directors' unlimited personal liability became cause for concern (Gelderblom et al. 2013).

To cover the shortfall between sales revenues and equipment costs the VOC took out insurance at a 5\% premium in 1613 . The contract was sold mainly to VOC shareholders and stipulated that, if revenues by August 1616 had fallen below 3.2 million guilders, the subscribers would have paid the difference. In the event, this did not happen (Gelderblom et al. 2011b). By guaranteeing the company as a going concern, the contract in effect shielded directors from an exposure to unlimited liability. In addition to the contract, the company pulled out all the stops to make ends meet, postponing dividend payments and raising short-term debt. Neither provided a final solution, and for several years the VOC finances continued to be based on revolving capital, profits from returning ships financing new expeditions and shortfalls being covered with small amounts of debt.

\footnotetext{
fleet, avoiding the need for a new capital call. When the next voyage was prepared in the Spring of 1613, the VOC directors came up with another way to tie in shareholders for a further three years, the 1613 insurance contract. When that lapsed in 1616 it was clear that the first account would be continued (Gelderblom et al. 2011b).

27. As we discuss later, the EIC also struggled in transferring assets across its much shorter subscriptions and shorter asset cycle.
} 
Financing also remained decentralized, with the different chambers borrowing separately and equipping their own fleets (Gelderblom et al. 2013).

Meanwhile new competitors began to arrive on the Asian scene, including a French company and the Austraelsche Compagnie established by le Maire, so the VOC directors raised their game. ${ }^{28}$ In 1615 they took the decision to send more ships and deal the competition a decisive blow by establishing an operational hub in Batavia. As sales revenues remained too low to fund the equipment of additional ships, the campaign was funded by issuing 8 million guilders' worth of debt between 1617 and 1623 (Gelderblom et al. 2013).

The directors' financial exposure sharply increased as a result of these loans because, just like the promissory notes traded on the Amsterdam money market since the late 16th century, they were secured on the person and goods of the person issuing them (Gelderblom and Jonker 2004). Thus, in order to limit each director's individual exposure to creditors' claims, the VOC in 1617 centralized financial policy; henceforth the individual chambers needed to ask permission to raise debt. At the same time, they transformed a director's individual exposure to liability into the pro rata liability of all directors by agreeing that they and their successors would underwrite debt raised. This allowed the company to borrow more easily from the Amsterdam money market, which offered better rates (Gelderblom et al. 2013).

Because unlimited liability provisions remained unaltered in the second VOC charter of 1623, directors had their officials sign obligations. The ensuing uncertainty as to who was liable was ended by a unilateral resolution later in 1623 by the directors to rewrite the text of their bonds and explicitly exclude any personal liability (Gelderblom et al. 2013). ${ }^{29}$ Critically, Dutch courts ultimately upheld the general nature of the exemption, a step that could not have been achieved without political support. From then on, the VOC as a legal entity was exclusively liable for its own debt (Punt 2010: 290-91). ${ }^{30}$ As we have observed, this corroborates the view that, differently from capital lock-in, limited liability could be (and was) introduced by a contractual innovation-even if later supported by the courts - rather than a legal innovation, and consequently that the law played a more important role in restricting claims on company assets than in protecting the investors' personal assets. The introduction of limited liability completed a two-decade-long process of slow coalescence of the missing building blocks of the corporate form.

28. On the first two ships sailing from France in 1615 and an earlier failed attempt to do so in 1604, see Du Fresne de Francheville (1738).

29. We do not have information as to whether this solution only concerned new bonds or also applied to bonds issued previously.

30. Punt (2010: 290) points out that, at the time, the VOC was not viewed as a legal person and directors were part of lawsuits against the company. Yet, by the 18th century, judgments would not be enforced against the directors personally but against the company. 


\section{The Political Economy of the Corporate Form}

The VOC's organizational model was highly effective. During the 17th century, the company outperformed all its European competitors sending more ships to Asia than all of them taken together (Figure 1), also dominating in terms of tonnage (Figure A1) and manpower (Figure A2). By 1795, five years before its de facto liquidation, the VOC had sent 4,785 ships and carried 3.4 million tons in the Asian trade, whereas the EIC had only managed 2,690 ships totaling 1.4 million tons. An impressive $59 \%$, in some decades rising to more than $70 \%$, of all the Europeans travelling to Asia during the VOC's two centuries of existence sailed with the company (Figure A3). This is remarkable for such a small country.

Here, we take a closer look at the comparative performance over time of the VOC and the EIC, its natural direct competitor (cf. De Vries 2003). The VOC vastly outperformed the EIC in terms of ships (Figure A6), tonnage (Figure A7), personnel (Figure A8) and sale revenues (Figure A9). The time series show the evolution of their relative performance. The EIC had a slower start but was regaining ground around the time of the VOC equity consolidation in 1612, then fell sharply behind. Its relative performance improved after 1657, when it also gained a permanent capital. However, the gap remained so big that it took several decades before the EIC regained a more or less level position.

Why did the EIC not emulate the VOC's consolidation of equity maturity earlier? This section offers an interpretation in terms of the different contexts in which the Dutch and English investors operated. We argue here that the critical factor holding back private commitment of long-term capital was the different political situation in the two countries. Commercial interests were never far from the minds of the urban representatives who dominated the Dutch Republic's seven provincial assemblies and the federal parliament, so there was a very low risk of public expropriation. Representatives also agreed on the VOC's political importance, which in the end persuaded them to grant de facto permanence. This stood in stark contrast to England, in 1602 still an absolute monarchy. Our model also has dynamic implications: when the English Parliament gained the upper hand, the willingness of English investors to commit to permanent EIC capital followed suit. The evidence we present also points out that the maturity of equity resulted in measurable differences in longterm investment and reinvestment policies.

\subsection{A Simple Model of Organizational Choice}

Since colonial trade had military implications, the political authority in each country shaped its organization. All countries involved in the Asian trade chose to run it through a monopoly, since pooling resources was efficient. Yet, pooling resources and committing long-term capital to a business venture generates agency costs (Berle and Means 1932). Managerial "negligence and profusion" in the colonial corporations was well recognized by Adam Smith and his contemporaries (Amsler et al. 
1981: 781). However, corporate governance issues cannot explain the sharp variation in financing models adopted at the time.

Spain and Portugal ran the Asian trade through state monopolies, while England and the Dutch Republic, as well as France and Denmark somewhat later, granted a monopoly privilege to private companies. Yet, there is no reason to believe that English and Dutch managers were to be trusted more than Spanish and Portuguese ones. In fact, the VOC management was believed to be quite corrupt, so much so that by the end of the 18th century wags said the company name meant "busted through corruption" (in Dutch "Vergaan Onder Corruptie"). Clearly, the profits that could be generated by the corporate form exceeded the associated agency cost. Why did the Dutch choose to accept these shortcomings of the corporate form ahead of others?

A large investment in long-term assets with military value was a tempting target for public authorities in any country. Countries where the expropriation risk was highest, such as Spain and Portugal, ran the Asian trade through a state monopoly, as the sole form able to sustain investment. At the other extreme, when central government power was limited, as in the Dutch Republic, private investment was not exposed to expropriation by the executive (North and Weingast 1989); hence investors were willing to lock in their capital.

At intermediate levels of expropriation risk - a stage that arguably describes England in the first half of the 17 th century ${ }^{31}$ - the central power was too unconstrained to resist the temptation to seize private resources with military value. As a result, investors pursued trade through shortterm partnerships. The limited investment scale and time horizon enabled investors to get repaid upon the return of the fleet. However, this recurrent liquidation structure encouraged investing in circulating capital rather than long-term capital assets. Even aside from public expropriation, trying to value and sell any fixed investment in a distant location to a new private company is subject to a serious hold-up problem. As a result, companies funded with short-term capital were unable to build up to an optimal scale of operations. Figure 4 illustrates our stylized model of organizational choice in a static environment.

\subsection{The Political Economy of the Dutch Republic and England}

At the beginning of the 17 th century, trade with Asia had a direct public interest, broader than the financial interest of traders. After the revolt against Spain, the novel Dutch state had crucial survival motives for chartering a company to challenge its Spanish enemies abroad and hence relieve direct military pressure. In England, the state interest in expansion

31. In France and Denmark, where the king had an intermediate degree of power, the solution resembled the early English model of repeated trade voyages with short capital commitment, run by private partnerships occasionally paying dues to the king for the privilege of an uncertain monopoly (Findlay and O'Rourke 2009). 


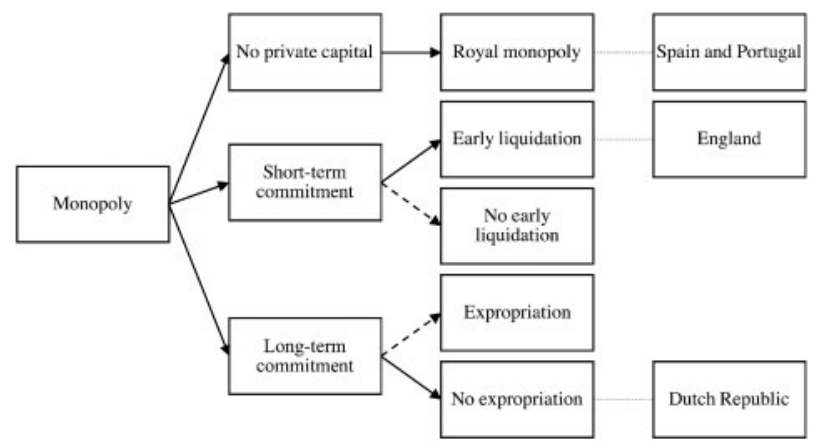

Figure 4. A Simple Model of Organizational Choice.

was evident throughout the history of the EIC, and ultimately morphed into England's colonial empire (Stern 2011). However, the different political institutions in the Dutch Republic and England shaped these companies' organizational strategies.

In the constitutional setup of the Dutch Republic there was no military leader to overrule the main representative assembly and force the primacy of military over commercial interests. This proved a critical factor to enable legal innovation (Harris 2009). ${ }^{32}$ From its inception in 1579, the Republic possessed a federal structure with cities handing over some authority to provinces, whose delegates bargained over foreign and military policy in the Estates General. Merchants had no direct voice in the assemblies, but an articulated political structure rooted in cities ensured that the Estates General were responsive to commercial interests (Gelderblom 2013). At the crucial junctures of 1602, when the VOC was chartered, and 1612, when its capital became permanent, commercial interests coincided with the Republic's military interests (Bouckaert 2015).

This stood in stark contrast to the situation in England. Until the middle of the 17th century, the English king had the power to call and dismiss Parliament at will. Parliamentary activity under James I and his successor Charles I was particularly restricted, considerably more so than under Elizabeth (Jha 2015). Chartered during this period, the EIC obtained a national monopoly on the Asian trade. However, the English king had great de facto discretion over the assignment of trading rights, and repeatedly allowed inroads on the EIC's monopoly in order to raise extra revenues.

32. Harris (2009) stresses the importance of limited government for the creation of a financial market. We refine this argument by highlighting its effect on capital commitment. Once capital became long-term, tradable shares became indispensable to counterbalance the loss of liquidity. In turn, this stimulated the development of stock markets. Intuitively, market development arose only once the basic property rights of corporate stock became protected. 
Historical evidence on the views held by EIC board members suggests that they fully recognized the inefficiency of chartering single voyages, and sought to move to a longer capital commitment cycle to fund more consecutive expeditions and larger fixed assets. ${ }^{33}$ The lengthening of the equity cycle was slow and subject to reversal in 1628-1631 (Figure 2). The willingness to invest long-term was certainly not aided by the uncertainty over the company's charter and monopoly status.

Until mid-century, the EIC could raise capital only on short maturity. The need to keep shareholders happy combined with its charter to ensure strict oversight by shareholders over managers, with more invasive investor control than in the VOC, relying on participation rights and a strict reporting of information on a regular basis (Harris 2005a: 28-31; 2005b: 229-32; 2009). The EIC's board of directors needed shareholder approval for major policy decisions including directors' remuneration, resulting in high payouts and low overseas investment (Scott 1912 Vol I: 154-59, 163). Apart from the dependence on capital supply, these choices may suggest either a concern to avoid agency cost or excessive exposure to public expropriation, or both (Coornaert 1967: 227). ${ }^{34}$

After dissolving Parliament in 1629, Charles I ruled without calling a new assembly for 11 years, creating strong opposition that led to the Long Parliament in 1640 and ultimately the Civil War of 1642-1648. Popular support for the constraining role of Parliament was strong (Hoppitt 2000), especially among the ranks of EIC investors (Jha 2015). Upon the Restoration of the Monarchy in 1660, the new King Charles II regained the power to call and dismiss Parliament, but the latter retained substantial control over state finances and, in particular, over the King's power to raise taxes (Cox 2012: 572), and in fact continued to meet yearly (Jha 2015).

Upon Charles II's death his brother James II manifested autocratic ambitions, soon faced a major insurrection and fled. The Glorious Revolution of 1688 crystallized once and for all the principle of limited government. Interestingly, the English chose as their new king William III of Orange, a Dutch stadhouder used to serve under a parliamentary mandate. He agreed to a Bill of Rights, which established the supremacy of Parliament and strengthened property rights (North and Weingast 1989; Rajan and Zingales 2003). ${ }^{35}$

33. See note 5 and accompanying text.

34. From an ex ante perspective, the greater oversight powers of the EIC shareholders indicate that the EIC shareholders were warier of expropriation and demanded (obtaining it) more voice than VOC shareholders. From an ex post perspective, this suggests that managers of the EIC were better controlled and hence could abuse their power less than the VOC managers. Both interpretations support our main argument that the risk of expropriation was larger in Britain and that internal governance issues cannot explain the better performance of the VOC.

35. Clark (1996) argues that returns on charities' assets (land, tithes, houses, rent charges, and private bonds) were unaffected over 1540-1837. Yet, the assets at risk of royal predation 
The evolution of political rights corresponds to a similar evolution in political thinking synchronized with the events. In the Roman tradition, the notion of fides publica embedded an obligation for officials invested with state power to act in the public interest (accountability). Conspicuously, the obligation was not simply a moral obligation, it had legal value. The first to rediscover this notion was the Dutch Hugo Grotius, who treated the notion in his work of youth, the Parallelon rerumpublicarum (Comparison of Republics) of 1602. Grotius returned to this notion in De iure belli ac pacis (On the Law of War and Peace, 1625). In England, the notion of fides publica began to circulate only later due to John Locke's Second Treatise of Government, published in 1689, just after the Glorious Revolution (de Wilde 2011).

Once England adopted limited government, it could also adapt its corporate model and match its colonial ambitions. In 1657, the EIC was finally able to move to permanent capital. The next sections detail the important differences between the VOC and the EIC: their different capital structure, exposure to expropriation risk and investment strategy.

\subsection{The Companies' Capital Structure}

The EIC was chartered on December 31, 1600 by Queen Elizabeth, who granted a group of 216 merchants a 15-year monopoly on trade with Asia. The monopoly covered all countries east of the Cape of Good Hope and west of the Straits of Magellan. The EIC followed conventional organizational practices and raised capital for one voyage at a time. For its initial voyage, the EIC raised slightly more than the equivalent of 700,000 guilders, whereas the VOC raised over 6.4 million guilders with 10-year maturity and rapidly called up all equity commitments. Figure 2 shows that the EIC capital lagged consistently behind the VOC. The EIC funded its first 12 voyages as separate enterprises with separate capital subscriptions. Profits were high, at times over $230 \%$ and were fully paid together with the principal within very few years. Only in 1613 did the EIC start experimenting with a medium-term commitment of capital in its First JointStock, lasting 8 years, at the time when the VOC had moved to permanent capital. The Second Joint-Stock followed in 1617 but thereafter the EIC continued to struggle with equity term commitments with a series of successive and partially overlapping joint-stock subscriptions. Between 1628 and 1631 the capital reversed to short-term financing in the three Persian Voyages. The Third Joint-Stock was established in 1631 (Chaudhuri 1965: 22, 209).

were those with public uses, such as local infrastructure (Bogart 2011) and foreign trading rights (Jha 2015). It is in these assets that investment boomed in volume and value after the Glorious Revolution. Significantly, in the years following the Glorious Revolution, both the number and the capitalization of joint-stock companies in England jumped up (Scott 1912, I: 439); likewise, public debt increased rapidly and substantially, signifying a lower perceived risk of expropriation (Harris 2009). On this debate, see also Epstein (2000) and O'Brien (2003). 


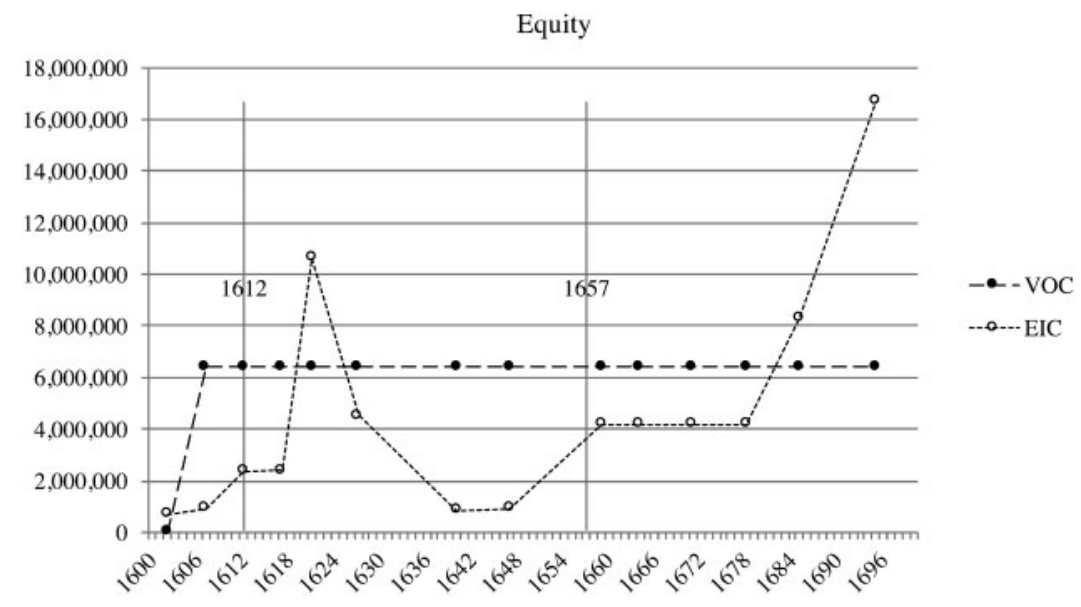

Figure 5. Equity Paid in, 1600-1700 (guilders).

Source: Scott (1912); Chaudhuri (1965); de Korte (1984); Gelderblom et al. (2013: Online Appendix).

The fluctuating capital of the EIC (Figure 5) was exposed to both uncertain renewals at each deadline and investors' demands for rapid profit distributions. The transition to an independent corporate entity took place after 1657, when the EIC was granted permanent capital.

Figure 6 compares the dividends paid to investors in England and the Dutch Republic. Up to 1608, pre-VOC Dutch companies had paid an estimated 21 million guilders in dividends, a vast amount roughly comparable to total EIC profits during its first 20 years. Thus, the rapid return of capital was standard in Dutch as well as London markets. In contrast, and surprisingly given its scale of operations, the VOC paid out relatively little during its first 30 years, consistently less than the EIC, because it reinvested at a high rate, ensuring faster growth and a larger market share.

By contrast, the EIC structure committed directors to pay out from cashflow rapidly to investors, the result of the shorter maturity of its equity (including dividends promised), the influence granted to investors, and the limited managerial discretion in its charter. Interestingly, the EIC and the VOC data cross around the time the EIC gained permanent capital, evidencing a sharp change in reinvestment policy.

Access to debt also differed between the two companies. The VOC could borrow at a lower, and decreasing, interest rate and it did so increasingly. Its interest rates fell after the VOC equity became permanent, even though borrowing accelerated. Debt rose again after 1623, when directors obtained limited liability (Figure 7). The EIC raised a smaller amount of funds through debt and may have faced a higher interest rate (see Figure 8). As the EIC struggled to finance operations in 1628 it had to borrow abroad, including in Amsterdam (Chaudhury 1965: 219-20). After 1657, the EIC replicated the strategy that the VOC had adopted almost 50 


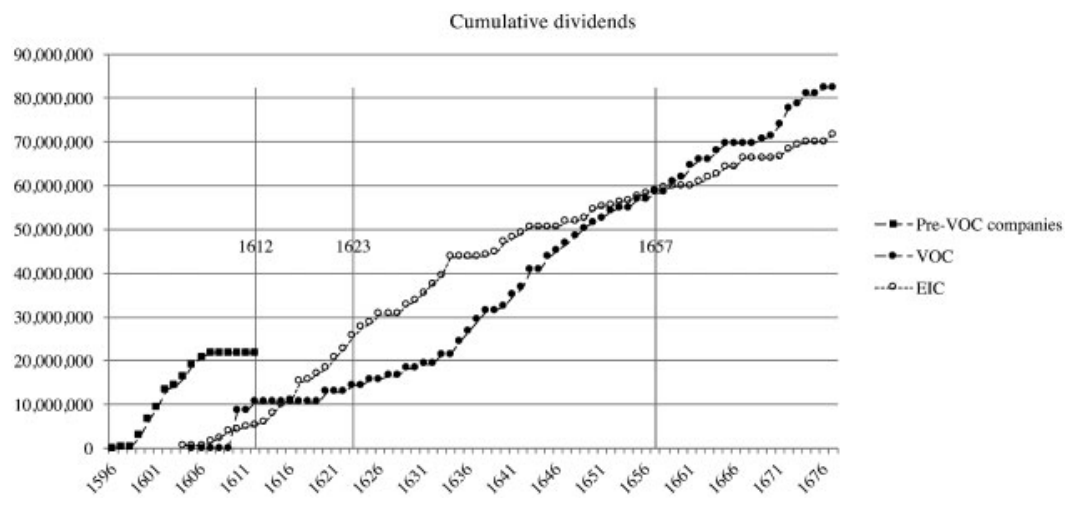

Figure 6. Cumulative Dividends 1596-1676 (guilders).

Source: Scott (1912, 91-113); Chaudhuri (1965: 207-23); Gelderblom (2009); Gelderblom et al. (2013: Online Appendix).

Debt

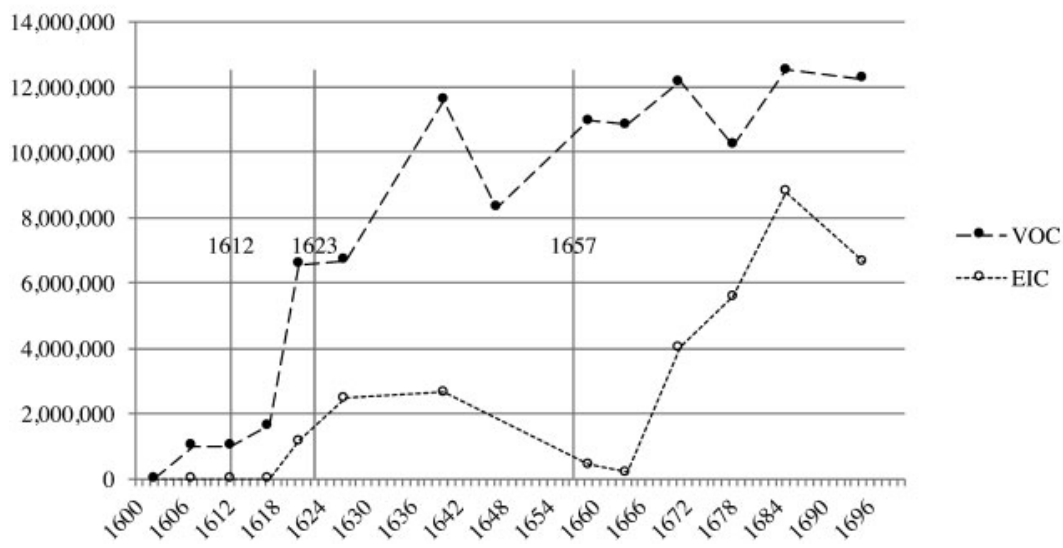

Figure 7. Debt 1600-1700 (guilders).

Source: Scott (1912: 91-113); Chaudhuri (1965); de Korte (1984); Gelderblom et al. (2013: Online Appendix).

years earlier, leveraging up its now stable equity structure to fund a sharp acceleration in investment.

\subsection{Expropriation Risk}

The reluctance of London merchants to invest long-term reflected limited trust in the English monarch's attitude. Queen Elizabeth's successor, King James I, granted charters to competing expeditions in 1601 and 1607, with an extension in 1609, in blatant disregard of the EIC charter (Scott 1912: 97-100). A similar cavalier attitude manifested itself as concerns the 


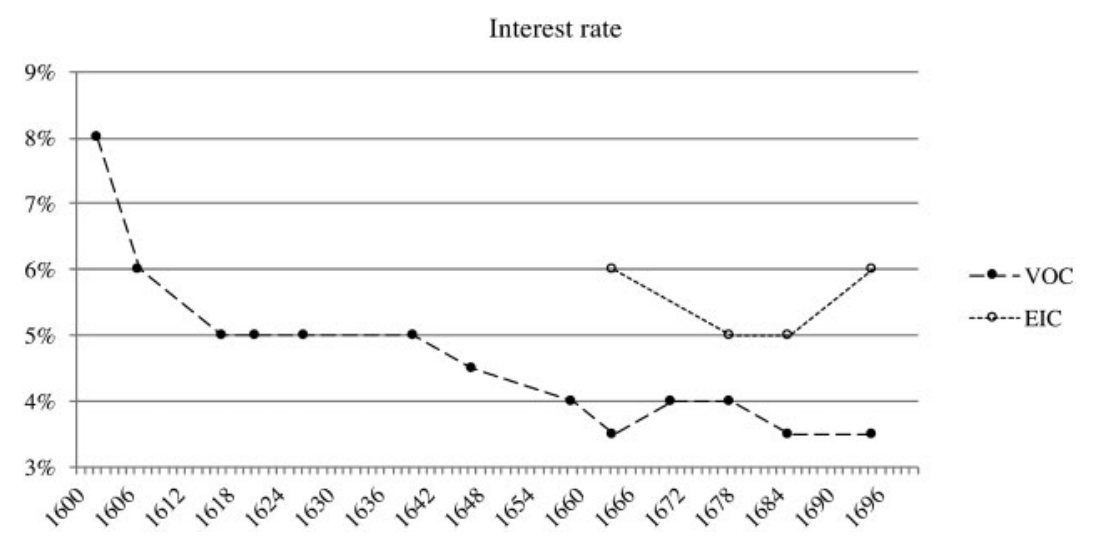

Figure 8. Interest Rates 1600-1700.

Source: Scott (1912: 91-113); Chaudhuri (1965); de Korte (1984); Gelderblom et al. (2013: Online Appendix).

enforcement of the EIC monopoly vis-à-vis private traders. Figure 9 depicts the number of interlopers for the EIC and the VOC.

The evidence suggests that, during the first half of the 17th century, the EIC faced a serious problem with political shifts leading to public and private monopoly infringements. The associated expropriation risk lasted until the Civil War. By contrast, the VOC could fight off the few instances in which individual traders challenged its monopoly. In fact, the VOC was able to undermine even a legitimate competitor who travelled via a westbound route to Asia, which was not covered by the monopoly (see Section 3.2.3). Even though the VOC ultimately lost in court, the lengthy litigation experience discouraged further attempts to test its monopoly.

\subsection{Long-Term Capital and Long-Term Investment}

The different equity structure of the two companies produced markedly different investment strategies. The VOC invested more than the EIC, but also differently, allocating substantially more resources into infrastructural investment. Quite contrary to the tradition of trading partnerships investing only in circulating assets, success during the early stages of the Asian trade required investment in circulating and fixed capital well in excess of short-term revenues. While the EIC at first pursued a rapid capital return cycle by promising dividends immediately upon return, the VOC soon engaged in systematic military spending, initially focusing on attacking Portuguese strongholds. Jan Pietersz Coen developed a twopronged strategy of establishing control over access to the Spice Islands in the Moluccas and building up a naval force to patrol the sea-lanes in the archipelago.

Once a central, fortified hub was established at Batavia in 1619, Coen directed the VOC's military efforts towards protecting the key routes to 


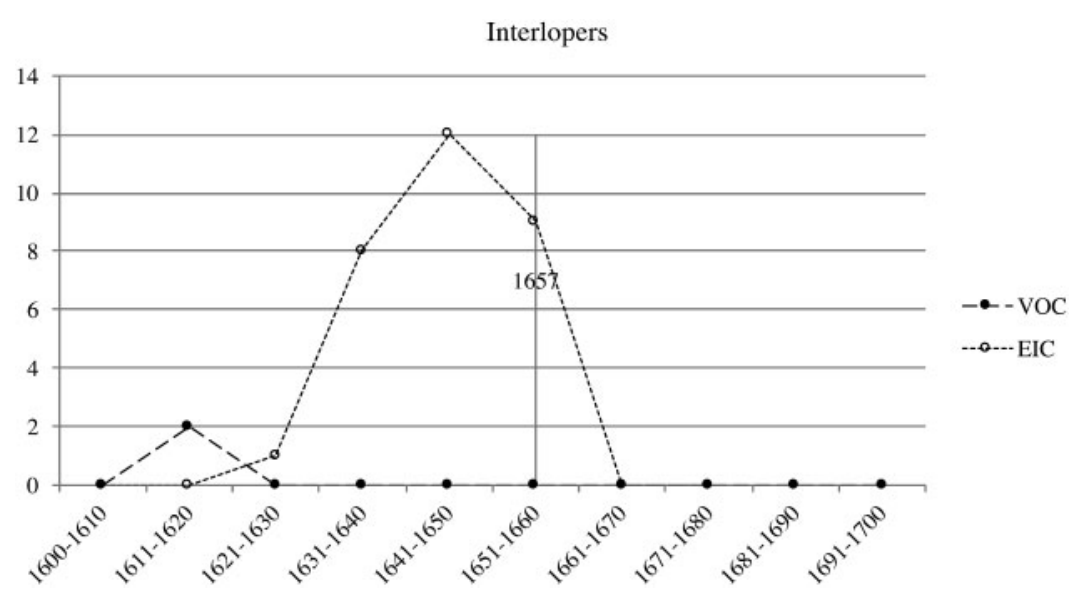

Figure 9. Interlopers 1600-1700 (number of incidents).

Source: van Dam (1927); Chaudhuri (1965; 1993); Steensgaard (1982).

the Moluccas, China, and Japan. None of the company's rivals came to muster comparable forces; by the early 1630 s the Dutch were master over the Indonesian archipelago. By the end of the 1650s the EIC started targeting India (Witteveen 2011), until then comparatively neglected. The Dutch sought to thwart English expansion even there by building several strongholds. It took several decades for the English to gain a clear preeminence in the region.

EIC officials regarded in so many words the VOC approach to expand the infrastructure overseas as a model to follow (Stern 2011: 19-21). Yet the EIC's frequent need to liquidate assets so as to pay shareholders created both a common-pool and a hold-up problem that stood in the way of long-term investment. As each individual voyage, and subsequently each joint-stock, was a separate enterprise with its own set of investors, any investment also benefited subsequent expeditions. Liquidation required selling remote assets to a new monopolistic venture, which also created a holdup problem and discouraged long-term investment. In contrast, the gains from VOC investments fully accrued to VOC investors. Figure 10 shows the massive scale of VOC investment in Asian assets. Importantly, the graph shows how the EIC investment jumped only after the Civil War, to reach a level comparable with the VOC once its capital had been consolidated.

Both companies needed to station ships in Asia with the task of providing security for the trading fleets and operating a network of inter-Asian trade. The VOC soon operated a much larger Asian fleet with an impressive record of over 100 ships around the 1660s (Figure 3). Until then the EIC was unable to maintain a comparable fleet. Figure 11 confirms how the VOC advantage was more pronounced in the Asian fleet. In the absence of fixed outposts, EIC ships were required to remain longer in Asia to secure the route, resulting in slower return voyages (Figure 12). 
Assets

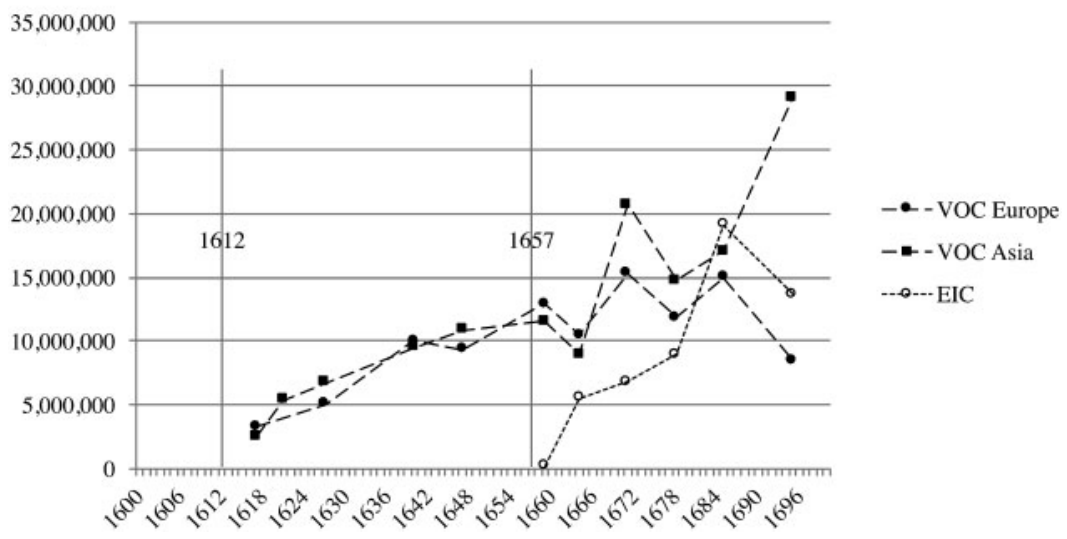

Figure 10. Assets 1600-1700 (guilders).

Source: Scott (1912); Chaudhuri (1965); de Korte (1984); Gelderblom et al. (2013: Online Appendix); National Archives The Hague, 1.11.01.01 (Aanwinsten Eerste Afdeling), Inv. Nr. 255.

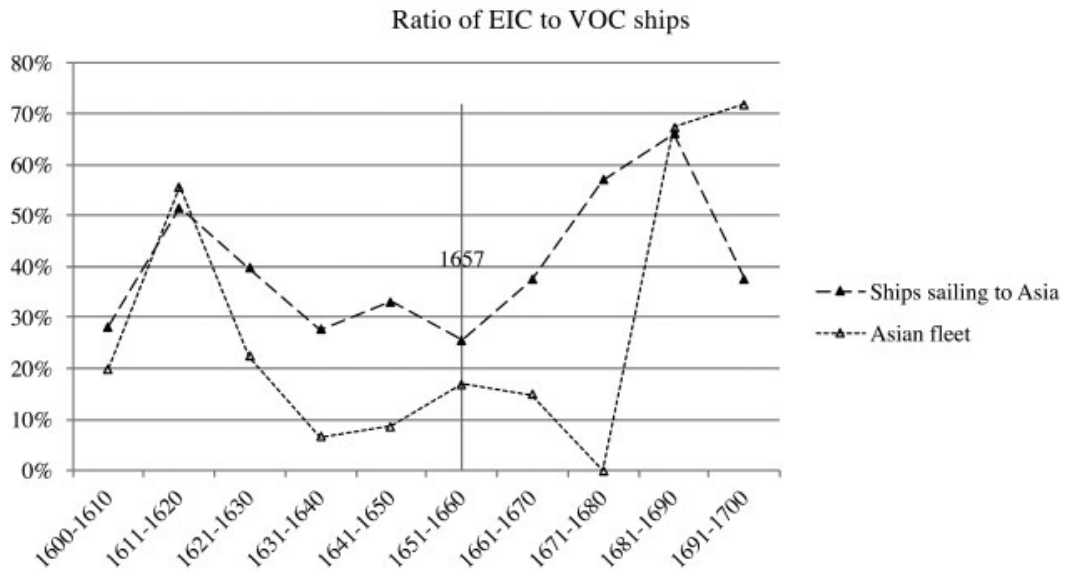

Figure 11. Ratio of EIC to VOC ships 1600-1700.

Source: van Dam (1927); Chaudhuri (1965; 1993); Bruijn et al. (1979-1987); Steensgaard (1982).

The rapid expansion in the EIC fleet size around the time of the Glorious Revolution again offers evidence supporting our interpretation.

\section{Conclusions}

A fundamental legal innovation took place in the early 17 th century, when what we now understand as corporate personhood became consolidated with the capital commitment achieved by the Dutch East India Company. 


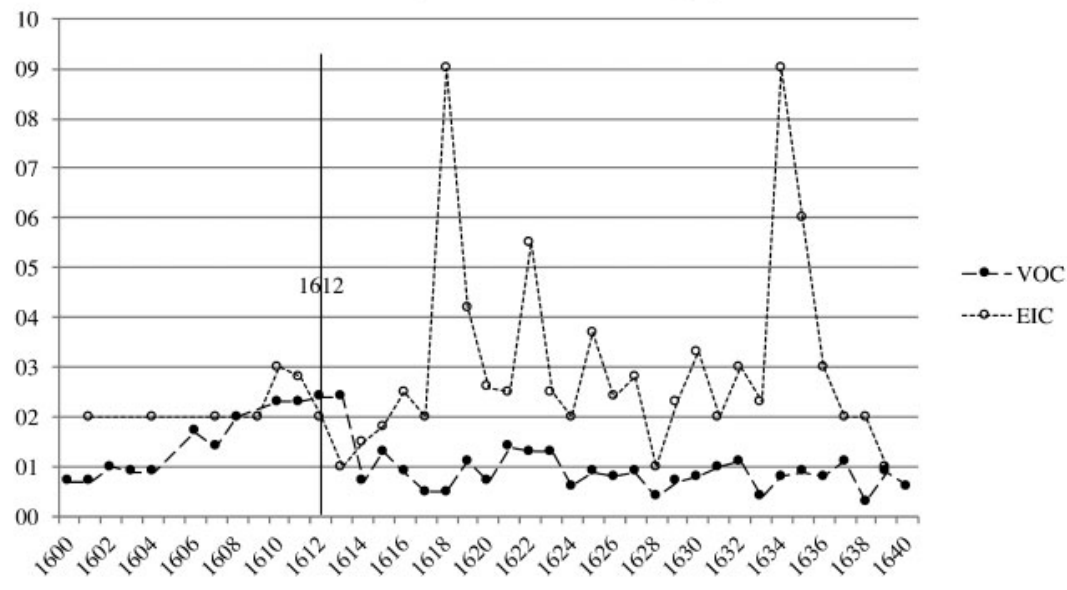

Figure 12. Average Duration of Return Voyages 1600-1640 (years).

Source: van Dam (1927); Chaudhuri (1965; 1993); Bruijn et al. (1979-1987); Steensgaard (1982).

We frame this advance in the context of earlier legal evolutions, and describe in detail how it came to emerge gradually at a critical historical juncture in the European race for South-East Asian trade.

Capital commitment implied a major step for investors, as they agreed to relinquish a fundamental individual legal right of withdrawal at will in order to create a long-term investment perspective. While it created the modern corporate governance conflict between owners and managers, capital lock-in enabled the VOC to gain a vast advantage in the Asia trade that would last many decades. Its emergence in the Dutch Republic ahead of its competitors was due to its limited form of government, which reduced the risk of expropriation by the political power. While other European countries were enticed by the enormous prospects of the Asian trade, it took them decades to be equally able to create large, permanent trading corporations. The English EIC continued to operate on short- and medium-term capital for half a century. Permanent capital was introduced only after the Civil War, when the arbitrary power of the crown was put under substantial parliamentary control.

There is evidence of a feedback loop between the development of the corporate form and the subsequent strengthening of private property rights. Acemoglu et al. (2005) show how access to colonial trade reinforced protection of property rights in societies with less autocratic institutions, as it strengthened trading interests over traditional elites. Joint-stock companies enabled any investor to take advantage of the new opportunities, supporting a broader coalition in favor of protecting the value of overseas investments. Jha (2015) presents unique empirical evidence that confirms how the development of joint stock companies influenced political support for parliamentary rule. By matching data on members of the English parliament 
with the EIC shareholder registers, he shows that shareholdings made individual members of Parliament more likely to favor Parliament in its struggle with the king, even after controlling for their status as noblemen or landowners.

By contrast, in countries when the gains from colonial trade went to the monarch or an aristocratic elite, such as in Spain or Portugal, they may have undermined the emergence of new economic subjects (Acemoglu et al. 2005). The Ottoman Empire, which ruled over the traditional land routes to the Far East replaced by the new Atlantic routes, suffered a significant economic loss, which may have contributed to undermine private initiatives to pool private capital. Kuran (2011) has argued that the failure to develop the corporate form had lasting economic effects on the region. Since their livelihood depended on the same land routes passing through the Ottoman Empire, also the Italian city-states such as Venice and Genoa suffered a significant economic loss, and went into secular decline. More generally, Mediterranean trading ports were not well positioned to take advantage of the new trade routes.

The corporate form was slowly adopted in other countries as their political institutions evolved. Yet, it remained a privilege granted by the state ad hoc to specific companies until the end of the 18th century, when general incorporation statutes began to spread (Lamoreaux and Rosenthal 2006: 127). Data on the United States show that, as local suffrage broadened and states needed to attract population and capital (Keyssar 2000), they were pushed to improve access to finance and relax restrictions on banking, credit, and incorporation (Butler 1985; Carney 1997; Benmelech and Moskowitz 2010; Rajan and Ramcharam 2011; Perotti 2014). By the end of the 19th century most western countries had moved to a parliamentary system with broader suffrage and the use of the corporate form had become broadly available (Harris 2000: 277-85; Guinnane et al. 2007).

The corporate form is now the foundation of the modern market economy. Its benefits are well appreciated: permanent capital grants an autonomous and indefinite life, and a capacity for long-term investment. This development in turn called for the open tradability of ownership claims and for limited liability, both essential for the development of modern financial markets.

While in western democracies the risk of expropriation is generally low, our analysis can shed light on the development of business institutions in developing countries or countries that recently underwent a process of democratization. In those cases we might observe a discontinuous drop in expropriation risk similar to the one we document in the 17 th century. Our analysis also relates to the active debate on short-termism versus long-termism in modern corporate governance scholarship. In a loose sense, our analysis points to the inherent long-term attitude of the corporate form. 
As for any major innovation, the full corporate status has had significant side effects, such as the emergence of the modern corporate governance conflicts. The creation of risk-shifting incentives associated with limited liability has also become very visible in default, and not least in the recent financial crises. These structural consequences highlight the significance of the transition achieved by its emergence.

\section{References}

Abatino, Barbara, Giuseppe Dari-Mattiacci, and Enrico C. Perotti. 2011. "Depersonalization of Business in Ancient Rome," 31 Oxford Journal of Legal Studies 365-89.

Acemoglu, Daron, Simon Johnson, and James Robinson. 2005. "The Rise of Europe: Atlantic Trade, Institutional Change, and Economic Growth," 95 American Economic Review 546-79.

Amsler, Christine E., Robin L. Bartlett, and Craig J. Bolton. 1981. "Thoughts of Some British Economists on Early Limited Liability and Corporate Legislation," 13 History of Political Economy 774-93.

Arangio-Ruiz, Vincenzo. 1993. Istituzioni di diritto romano. 14th ed. Napoli: Jovene.

Armour, John, and Michael J. Whincop. 2007. "The Proprietary Foundations of Corporate Law," 27 Oxford Journal of Legal Studies 429-65.

Armour, John, Henry Hansmann, and Reinier Kraakman. 2009. "What is Corporate Law?" in R. Kraakman, J. Armour, P. Davies, L. Enriques, H. Hansmann, G. Hertig, K. Hopt, H. Kanda, and E. Rock, eds., The Anatomy of Corporate Law. A Functional Approach. 2nd ed., 1-34. Oxford: Oxford University Press.

Bakhuizen van den Brink, Reinier C. 1865. "Isaac Lemaire", 29 De Gids 1-56.

Benmelech, Efraim, and Tobias J. Moskowitz. 2010. "The Political Economy of Financial Regulation: Evidence from US State Usury Laws in the $19^{\text {th }}$ Century," 65 Journal of Finance 1029-73.

Berle, Adolf A., and Gardiner C. Means. 1932. The Private Corporation and Private Property. New York: Macmillan.

Bieleman, Jan. 1992. Geschiedenis van de landbouw in Nederland, 1500-1950: Veranderingen en verscheidenheid. Meppel: Boom.

Blair, Margaret. 2003. "Locking in Capital: What Corporation Law Achieved for Business Organizers in Nineteen Century America," 51 UCLA Law Review 387-455.

- 2013. "The Four Functions of Corporate Personhood," in A. Grandori, ed., Handbook of Economic Organization, 440-61. Cheltenham: Edward Elgar.

Bogart, Daniel E. 2011. "Did the Glorious Revolution Contribute to the Transport Revolution? Evidence from Investment in Roads and Rivers," 64 Economic History Review 1073-112.

Bouckaert, Boudewijn. 2015. "Institutions Matter: Explaining Successes of the Dutch Republic (1568-1795).” Mimeo, Harvard Lecture.

Bruijn, Jaap R., Femme S. Gaastra, and Ivo Schöffer. 1979-1987. Dutch-Asiatic Shipping in the 17th and 18th Centuries, 3 vols. Nijhoff: The Hague.

Butler, Henry N. 1985. "Nineteenth-Century Jurisdictional Competition in the Granting of Corporate Privileges," 14 Journal of Legal Studies 129-66.

Carlos, Ann M., and Stephen Nicholas. 1996. "Theory and History: Seventeenth-century Joint-stock Chartered Trading Companies," 56 Journal of Economic History 916-24.

Carney, William J. 1997. "The Political Economy of Competition for Corporate Charters," 26 Journal of Legal Studies 303-29.

Chaudhuri, Kirti N. 1965. The English East India Company: The Study of an Early JointStock Company 1600-1640. Cass: London 
1978. The Trading World of Asia and the English East India Company 1660-1760. Cambridge: Cambridge University Press.

1993. "The English East India Company's Shipping (c. 1660-1760)," in J. R. Bruijn, and F. Gaastra, eds., Ships, Sailors and Spices. East India Companies and Their Shipping in the 16th, 17th, and 18th Centuries, 49-80. Amsterdam: NEHA.

Clark, Gregory. 1996. "The Political Foundations of Modern Economic Growth: England 1540-1800," 26 Journal of Interdisciplinary History 563-88.

Colenbrander, Herman T. 1934. Jan Pietersz. Coen, levensbeschrijving, Nijhoff: The Hague.

Coornaert, Émile L. J. 1967. "European Economic Institutions and the New World; the Chartered Companies," in E. E. Rich and C. H. Wilson. eds., The Cambridge Economic History of Europe from the Decline of the Roman Empire, vol. 4, 220-74. Cambridge: Cambridge University Press.

Cox, Gary W. 2012. "Was the Glorious Revolution a Constitutional Watershed?," 72 Journal of Economic History 567-600.

de Jong, Abe, Joost Jonker, and Ailsa Röell. 2013. "Dutch Corporate Finance, 1602-1850," in G. Caprio, ed., Handbook of Key Global Financial Markets, Institutions, and Infrastructure, vol. 1, 73-83. Oxford: Elsevier.

de Korte, J. P. 1984. De jaarlijkse financiële verantwoording in de Verenigde Oostindische Compagnie. Den Haag: Nijhoff.

De Ruysscher, Dave. 2016. "A Business Trust for Partnerships? Early Conceptions of Company-Related Assets in Legal Literature and Antwerp Forensic and Commercial Practice (Later Sixteenth-Early Seventeenth Century)," in B. van Hofstraeten, and W. Decock, eds., Companies and Company Law in Late Medieval and Early Modern Europe, 9-27. Leuven: Peeters.

De Vries, Jan. 1974. The Dutch Rural Economy in the Golden Age, 1500-1700. New Haven: Yale University Press.

- 2003. "Connecting Europe and Asia: A Quantitative Analysis of the Cape-route Trade, 1497-1795" in D. O. Flynn, and A. Giraldez, eds., Global Connections and Monetary History, 1470-1800, 35-105. Ashgate: Aldershot.

de Wilde, Marc. 2011. "Fides publica in Ancient Rome and its Reception by Grotius and Locke," 79 Legal History Review 455-87.

Demsetz, Harold. 1967. "Toward a Theory of Property Rights," 57 American Economic Review 347-59.

den Heijer, Hendrik J. 2005. De geoctrooieerde compagnie, de VOC en de WIC als voorlopers van de naamloze vennootschap. Deventer: Kluwer.

Du Fresne de Francheville, Joseph. 1738. Histoire de la Compagnie des Indes avec les titres de ses concessions et privileges. Paris: Chez De Bure l'Aîné.

Easterbrook, Frank H., and Daniel R. Fischel. 1991. The Economic Structure of Corporate Law. Cambridge, MA: Harvard University Press.

Epstein, Stefan. R. 2000. Freedom and Growth: The Rise of States and Markets in Europe, 1300-1750. London: Routledge.

Favali, Lydia. 2004. Qirad islamico, commenda medievale e strategie culturali dell'occidente. Torino: Giappichelli.

Findlay, Ronald, and Kevin H. O'Rourke. 2009. Power and Plenty. Trade, War, and the World Economy in the Second Millennium. Princeton: Princeton University Press.

Fleckner, Andreas. 2010. Antike Kapitalvereinigungen: Ein Beitrag zu den konzeptionellen und historischen Grundlagen der Aktiengesellschaft. Cologne: Boehlau.

- Forthcoming. "Roman Business Associations," in G. Dari-Mattiacci , ed., Roman Law and Economics, vol. 1. Oxford: Oxford University Press.

Gaastra, Femme. 2007. De geschiedenis van de VOC, Walburg Pers: Zutphen.

Gelderblom, Oscar. 2003. "From Antwerp to Amsterdam: The Contribution of Merchants from the Southern Netherlands to the Rise of the Amsterdam Market," 26 Review. A Journal of the Fernand Braudel Center 247-83. 
2009. "The Organization of Long-Distance Trade in England and the Dutch Republic, 1550-1650," in O. Gelderblom, ed., The Political Economy of the Dutch Republic, 223-54. Aldershot: Ashgate.

- 2013. Cities of Commerce. The Institutional Foundations of International Trade in the Low Countries, 1250-1650. Princeton: Princeton University Press.

Gelderblom, Oscar, and Joost Jonker. 2004. "Completing a Financial Revolution: The Finance of the Dutch East India Trade and the Rise of the Amsterdam Capital Market, 1595-1612," 64 The Journal of Economic History 641-72.

Gelderblom, Oscar, Abe de Jong and Joost Jonker. 2011a. "An Admiralty for Asia. Isaac le Maire and Conflicting Conceptions about the Corporate Governance of the VOC," in J. G. S. Koppell, ed., The Origins of Shareholder Advocacy, 29-60 New York: Palgrave Macmillan.

Gelderblom, Oscar, Abe de Jong, and Joost Jonker. 2011b. "The VOC Insurance Contract of 1613," working paper.

- 2013. "The Formative Years of the Modern Corporation: The Dutch East India Company (VOC), 1602-1623," 73 Journal of Economic History 1050-76.

Glamann, Kristof. 1981. Dutch-Asiatic Trade 1620-1740. The Hague: Nijhoff.

Goetzmann, William N., and Sebastien Pouget. 2011. "A Shareholder Lawsuit in fourteenth Century Toulouse,” in J. G. S. Koppell, ed., Origins of Shareholder Advocacy, 215-29. New York: Palgrave-MacMillam.

Goetzmann, William N., David le Bris, and Sebastien Pouget. 2015. "Modern Introduction to Germain Sicard's The Mills of Toulouse," in W. N. Goetzmann, ed., M. Landry, trans., Germain Sicard. The Origins of Corporations. The Mills of Toulouse in the Middle Ages. Yale: Yale University Press.

Grossman, Sanford J., and Oliver D. Hart. 1986. "The Costs and Benefits of Ownership: A Theory of Vertical and Lateral Integration," 94 Journal of Political Economy 691-719.

Guinnane, Timothy, Ron Harris, Naomi R. Lamoreaux, and Jean-Laurent Rosenthal. 2007. "Putting the Corporation in its Place," 8 Enterprise and Society 687-729.

Haak, Sikko P., and Augustus J. Veenendaal. 1962. Johan van Oldenbarnevelt. Bescheiden betreffende zijn staatkundig beleid en zijn familie, vol. 2, 1602-13. Nijhoff: The Hague.

Hansmann, Henry, and Reinier H. Kraakman. 2000a. "The Essential Role of Organizational Law," 110 Yale Law Journal 387-440. $807-17$. 2000b. "Organizational Law as Asset Partitioning," 44 European Economic Review

. 2002. "Property, Contract and Verification: The Numerus Clausus Problem and the Divisibility of Rights," 31 Journal of Legal Studies S373-S420.

Hansmann, Henry, Reinier H. Kraakman, and Richard Squire. 2006. "Law and the Rise of the Firm," 119 Harvard Law Review 1335-403.

. Forthcoming. "Incomplete Organizations: "Legal Entities and Asset Partitioning in Roman Commerce," in Dari-Mattiacci Giuseppe (ed.), Roman Law and Economics, vol. 1. Oxford: Oxford University Press.

Harris, Ron. 2000. Industrializing English Law: Entrepreneurship and Business Organization, 1720 - 1844. Cambridge: Cambridge University Press.

—. 2005a. "The Formation of the East India Company as a Cooperation-Enhancing Institution," working paper, Tel Aviv University.

- 2005b. "The English East India Company and the History of Company Law," in E. Gepken-Jager, G. van Solinge, and L. Timmerman, eds., VOC 1602-2002 - 400 Years of Company Law, Deventer: Kluwer Legal Publishers.

- 2009. "Law, Finance and the First Corporations," in J. J. Heckman, R. L. Nelson, and L. Cabatingan, eds., Global Perspectives on the Rule of Law. Abingdon: RoutledgeCavendish.

Hart, Oliver D., and John Moore. 1990. "Property Rights and the Nature of the Firm," 98 Journal of Political Economy 1119-58.

Hoppitt, Julian. 2000. A Land of Liberty? England, 1689-1727. Oxford: Oxford University Press. 
Hunt, Edwin S. and James Murray. 1999. A History of Business in Medieval Europe, 12001550. Cambridge: Cambridge University Press.

Jansen, Jan. 1645. Nederlantsche Munt-Boeck, vervatende de voornaemste placcaten ende ordonnantien, de Munte, ende het Munt-wesen betreffende, geemaneert ende uytgegeven in de vereenighde Nederlantsche Provinten, sedert den Jaere 1580 tot in den loopende Jare 1645. Amsterdam: J. Jansen.

Jensen, Michael C., and William H. Meckling. 1976. "Theory of the Firm: Managerial Behavior, Agency Costs and Ownership Structure," 3 Journal of Financial Economics 305-60.

Jha, Saumitra 2015. "Financial Asset Holdings and Political Attitudes: Evidence from Revolutionary England," 130 Quarterly Journal of Economics 1485-545.

Jones, Stephen R. H., and Simon P. Ville. 1996a. "Efficient Transactors or Rent-Seeking Monopolists? The Rationale for Early Chartered Trading Companies," 56 Journal of Economic History 898-915.

- 1996b. "Theory and Evidence: Understanding Chartered Trading Companies," 56 Journal of Economic History 925-27.

Kessler, Amalia D. 2003. "Limited Liability in Context: Lesson from the French Origins of the American Limited Partnership," 32 Journal of Legal Studies 511-48.

Keyssar, Alexander. 2000. The Right to Vote: The Contested History of Democracy in the United States. New York: Basic Books.

Knaap, Gerrit, Hendrink J. den Heijer, Michiel de Jong, Thijs Brocades Zaalberg, and Petra Groen. 2015. Oorlogen overzee: militair optreden door compagnie en staat buiten Europa 1595-1814. Amsterdam: Boom.

Kuran, Timur. 2011. The Long Divergence: How Islamic Law Held Back the Middle East. Princeton: Princeton University Press.

Lamoreaux, Naomi R., and Jean-Laurent Rosenthal. 2006. "Corporate Governance and the Plight of Minority Shareholders in the United States before the Great Depression," in E. L. Glaeser, and C. Goldin, eds., Corruption and Reform: Lessons from America's Economic History, 125-52. Chicago: University of Chicago Press.

Macey, Jonathan. 1999. "Fiduciary Duties as Residual Claims: Obligations to Nonshareholder Constituencies from a Theory of the Firm Perspective," 84 Cornell Law Review 1266-81.

Malmendier, Ulrike. 2009. "Law and Finance at the Origin," 47 Journal of Economic Literature 1076-108.

Mignone, Gianni. 2005. Un contratto per i mercanti del Mediterraneo. Napoli: Jovene.

Montanari, Massimo. 1990. Impresa e responsabilità. Sviluppo storico e disciplina positive. Milano: Giuffrè.

North, Douglass C. 1990. Institutions, Institutional Change and Economic Performance. Cambridge: Cambridge University Press.

North, Douglass C., and Barry R. Weingast. 1989. "Constitutions and Commitment: The Evolution of Institutions Governing Public Choice in Seventeenth-Century England," 49 Journal of Economic History 803-32.

O'Brien, Patrick K. 2003. "Fiscal Exceptionalism: Great Britain and Its European Rivals: From Civil War to Triumph at Trafalgar and Waterloo," in P. O'Brien and D. Winch, eds., The Political Economy of British Historical Experience, 1688-1914, 245-66. Oxford: Oxford University Press.

Parthesius, Robert. 2010. Dutch Ships in Tropical Waters. The development of the Dutch East India Company (VOC) shipping network in Asia 1595-1660. Amsterdam: Amsterdam University Press.

Perotti, Enrico C. 2014. "The Political Economy of Finance," 9 Capitalism and Society Article 1.

Petram, Lodewijk. 2011a. "The World's First Stock Exchange." PhD dissertation, University of Amsterdam.

— 2011b. De bakermat van de beurs. Hoe in zeventiende-eeuws Amsterdam de moderne aandelenhandel ontstond. Amsterdam: Atlas. 
Poelwijk, Arjan. 2003. “In Dienste vant Suyckerbacken”. De Amsterdamse suikernijverheid en haar ondernemers, 1580-1650. Hilversum: Verloren.

Punt, Hendrik M. 2010. "Het vennootschapsrecht van Holland." Ph.D. dissertation, University of Leiden.

Rajan, Raghuram G., and Luigi Zingales. 2003. Saving Capitalism from the Capitalists: Unleashing the Power of Financial Markets to Create Wealth and Spread Opportunity. New York: Crown business.

Rajan, Raghuram, and Rodney Ramcharan. 2011. "Land and Credit: A Study of the Political Economy of Banking in the United States in the Early 20th Century," 66 Journal of Finance 1895-931.

Rijpma, Auke. 2012. "Funding Public Services through Religious and Charitable Foundations in the Late-Medieval Low Countries." Ph.D. dissertation, Utrecht University

Robertson, Jeffrey, and Warwick Funnell. 2012. "The Dutch East-India Company and Accounting for Social Capital at the Dawn of Modern Capitalism 1602-1623," 37 Accounting, Organizations and Society 342-61.

Sainsbury, Ethel Bruce, and William Foster. 1907-1938. A Calendar of the Court Minutes etc. of the East India Company, 1635-1679. Oxford: Clarendon Press.

Schwartz, Andrew A. 2012. "The Perpetual Corporation," 80 George Washington Law Review 764-830.

Scott, William R. 1912 (reprint 1968). The Constitution and Finance of English, Scottish, and Irish Joint-Stock Companies to 1720, 3. vols. Gloucester Mass: P. Smith.

Shareholder Rights at 400, Commemorating Isaac Le Maire and the First Recorded Expression of Investor Advocacy, APG: s.1. 2009.

Sicard, Germain. 1953. Les Moulins de Toulouse au Moyen Age. Paris: Armand Colin.

Steensgaard, Niels. 1982, "The Dutch East India Company as an Institutional Innovation," in M. Aymard, ed., Dutch Capitalism and World Capitalism. 235-57. Cambridge: Cambridge University Press.

Stern, Philip J. 2011. The Company-State, Oxford: Oxford University Press.

Stout, Lynn A. 2005. "On the Nature of Corporations," 2005 University of Illinois Law Review 253-68.

van Bavel, Bas, and Oscar Gelderblom. 2009. "The Economic Origins of Cleanliness in the Dutch Golden Age," 205 Past and Present 41-69.

van Dam, Pieter. 1927. Beschryvinge van de Oostindische Compagnie, F.W. Stapel, ed., The Hague: Nijhoff.

van der Linden, Hendrik. 1955. De Cope. Bijdrage tot de rechtsgeschiedenis van de openlegging der Hollands-Utrechtse laagvlakte. Assen: van Gorcum.

van Dillen, Johannes G. 1930. "Isaac le Maire en de handel in actiën der Oost-Indische Compagnie," 16 Economisch-historisch jaarboek 1-165.

- 1958. Het oudste aandeelhoudersregister van de Kamer Amsterdam der Oost-Indische Compagnie. The Hague: Nijhoff.

van Tielhof, Milja. 2009. "Financing Water Management in Rijnland, 1500-1800," in O. Gelderblom, ed., The Political Economy of the Dutch Republic. 197-222. Aldershot: Ashgate.

van Zwet, Han. 2009. Lofwaerdighe dijckagies en miserabele polders. Een financiële analyse van landaanwinningsprojecten in Hollands Noorderkwartier, 1597-1643. Hilversum: Verloren.

Alan Watson, ed., 2009. The Digest of Justinian. Philadelphia: University of Pennsylvania Press.

Witteveen, Menno. 2011. Antonio van Diemen. De opkomst van de VOC in Azië. Amsterdam: Pallas Publicaties.

Yntema, Richard J. 1992. "The Brewing Industry in Holland, 1300-1800: A Study in Industrial Development." Ph.D. dissertation, University of Chicago.

Zimmernann, Reinhard. 1996. The Law of Obligations: Roman Foundations of the Civilian Tradition. Oxford: Oxford University Press.. 


\section{Appendix}

\section{Datasets and Data Limitations}

Even though a large part of the business administration of the VOC in the first half of the 17th century has not survived, historians have been able to reconstruct the company's business operations in considerable detail. For this article we have collated previously collected evidence on the company's shipping operations (Bruijn et al. 1979-1987), personnel (De Vries 2003), and sales since 1642 (de Korte 1984). For individual years we drew additional information on sales from Glamann (1981) and from a private memo written by one of the company directors in 1618 (National Archives NA 1.11.01.01 (Aanwinsten Eerste Afdeling), Inv. Nr 255, fol. 7879) We have also used data from a previous reconstruction of the VOC's finances in the first 20 years of its existence (Gelderblom et al. 2013, Online Appendix).

Nothing survives of the detailed accounts kept by the EIC from its creation in 1600 (Chaudhuri 1965: 208). The ledgers with capital subscriptions and dividend payments are no longer available, nor do we have at our disposal the accounts of the treasurers, who kept cash receipts, loan issues, interest payments and loan redemptions. Furthermore, we know next to nothing about expenditures on ships and personnel sent to Asia, or the financial flows within Asia in the first half of the 17th century. All that remains are three partial tabulations of capital investments, dividend payments, and incidental loans and stock prices for various years in this period. Chaudhuri (1965), and Scott (1912) before him, have turned these documents into tractable overviews of revenues and spending, albeit without the level of detail available for the VOC in this period. For our reconstruction of EIC shipping we have appended Chaudhuri's overview with shipping data from the company's Court Minutes, edited by Sainsbury and Foster (1907-1938).We converted pounds sterling into guilders at the actual exchange rate for the years concerned on the basis of Jansen (1645) (Courtesy Marcel van der Beek of the former Dutch Money Museum).

\section{European Competitors}

Figures A1, A2 and A3 illustrate the performance of the VOC as compared with its European competitors. The data on tonnage and personnel clearly shows that the VOC dominated the Asian trade by a large margin, outperforming all of its competitors taken together. 
Tonnage of ships sailing to Asia

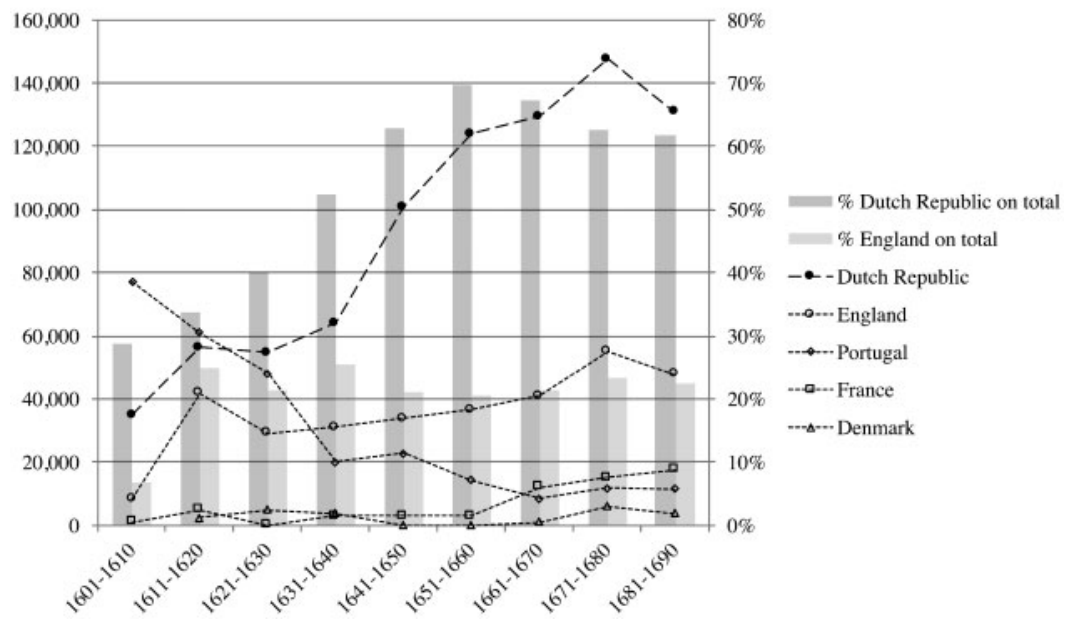

Figure A1. Tonnage of ships sent from Europe to Asia, 1600-1690 (tons). Source: De Vries 2003.

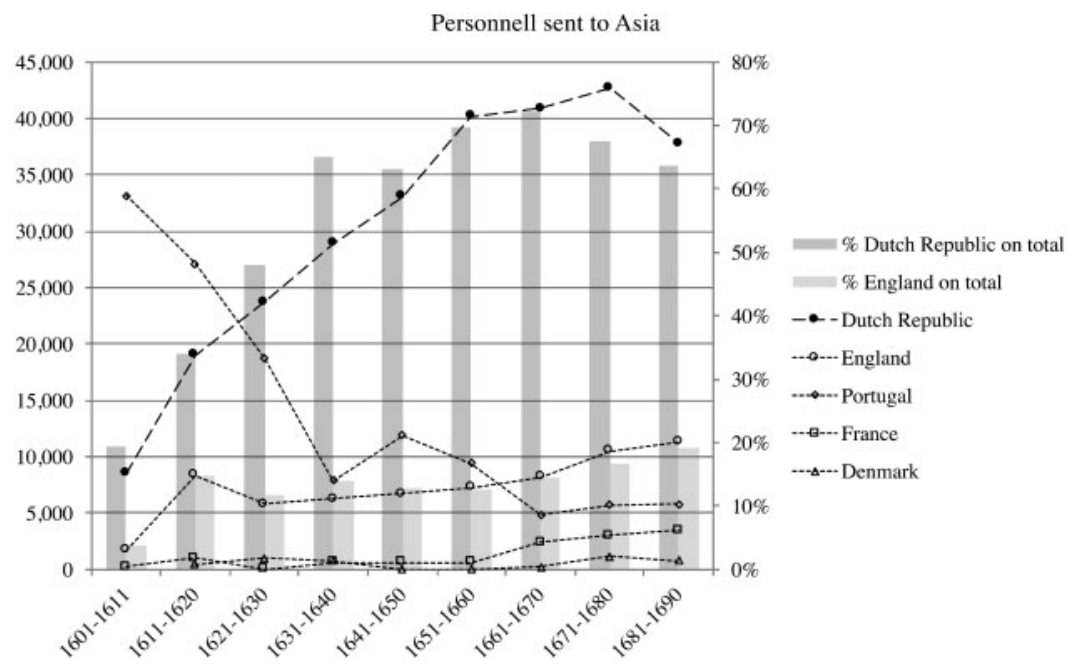

Figure A2. Personnel sent from Europe to Asia, 1600-1690 (number of people onboard). Source: De Vries (2003: 69-70). 


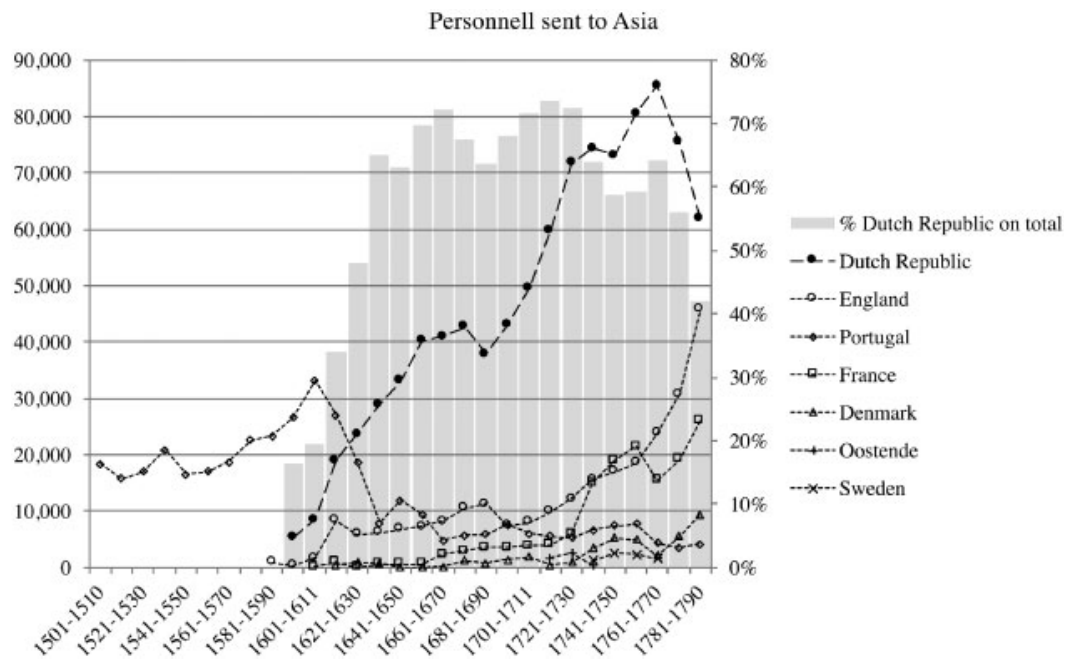

Figure A3. Personnel sent from Europe to Asia, 1600-1790 (number of people on board). Source: De Vries (2003: 69-70).

\section{The Effects of a more Efficient Organizational Model}

The relative strength of the EIC and VOC in the first part of the 17th century can be appreciated by comparing English and Dutch employment and investment in ships sailing to Asia. Figure A4 and Figure A5 show that the Dutch rapidly pulled ahead of the English. The Dutch invested 14 million guilders between 1600 and 1607, against 2.2 million guilders for the EIC. After some difficult years the Dutch invested 12.4 million guilders in seven fleets sailing between 1610 and $1616 .{ }^{36}$

Direct evidence of the commercial competition in this period comes from correspondence of VOC directors with its Asian governors. Coen reported closely on English fleet movements and skirmishes with VOC vessels (Colenbrander 1934: 45, 65, 69-70, 93-94, 117, 132, 139-43, 152-53). Coen's greatest concern was that whereas the VOC used a considerable part of its ships, crews, and silver for military operations, the English used the bulk of their resources to buy as many spices as possible to dispatch to Europe (Colenbrander 1934: 79). Coen observed that the English were free-riding on Dutch military efforts to secure the area and inspired a major policy change, visible in Figure A4. From 1616, the VOC sent out larger fleets with more silver to buy up spices ahead of the English (Colenbrander 1934: 69, 93, 149; Gelderblom et al. 2013). The speed and scale of this strategic shift clearly depended on the sustained capital commitment.

36. In 1608 prospective shareholders were unwilling to advance their money for the equipment of a new fleet, hence the EIC had to borrow to start preparations (Scott 1912: 100). 


\section{Investments in fleets}

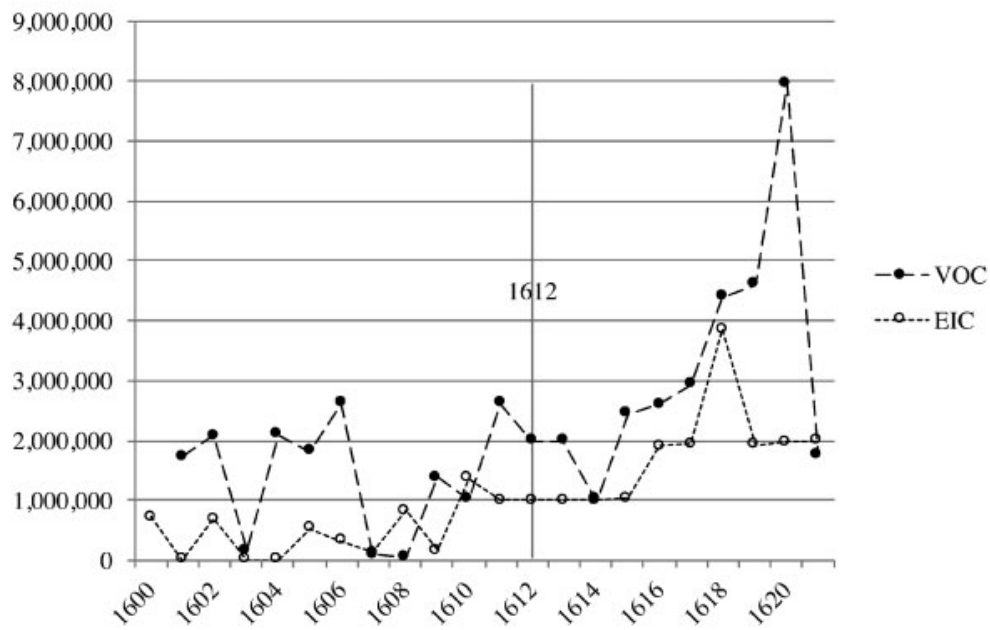

Figure A4. Dutch and English investments in ships sailing to Asia, 1600-1621 (guilders). Source: van Dam (1927); Chaudhuri (1965; 1993); Bruijn et al. (1979-1987); Steensgaard (1982).

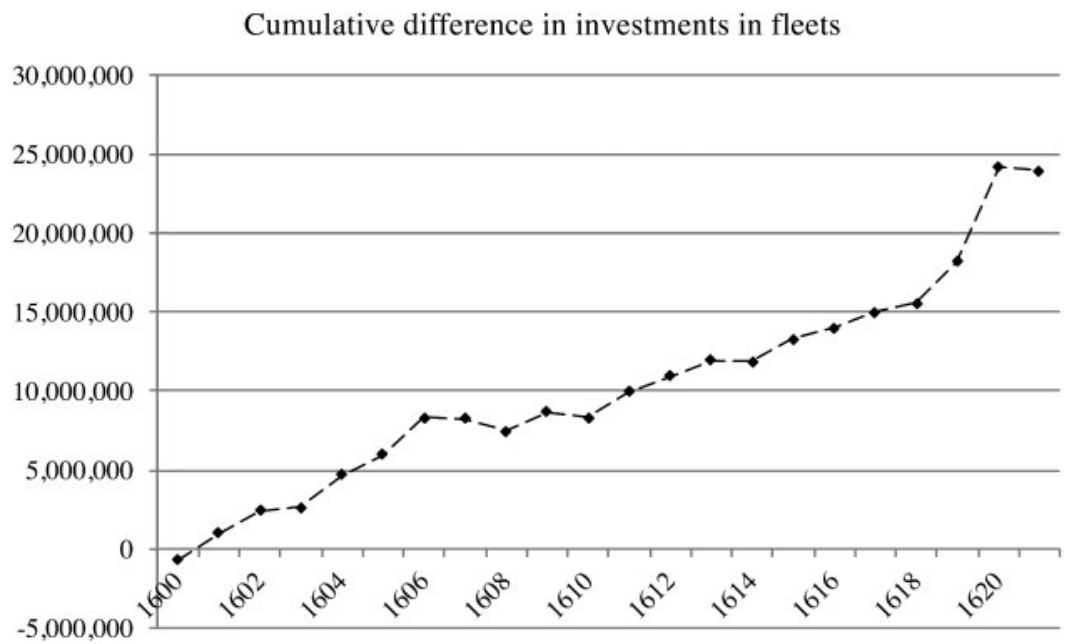

Figure A5. Cumulative difference of Dutch and English investments in ships sailing to Asia, 1600-1621 (guilders).

Source: van Dam (1927); Chaudhuri (1965; 1993); Bruijn et al. (1979-1987); Steensgaard (1982).

In contrast, the initial EIC subscriptions were very profitable - each of the six fleets sailing between 1610 and 1612 turned a profit between $50 \%$ and $200 \%$ - but too short (Chaudhury 1965). In the attempt to increase the scale of operations, in 1613 the First Joint-Stock raised a capital of 4.2 
Ships

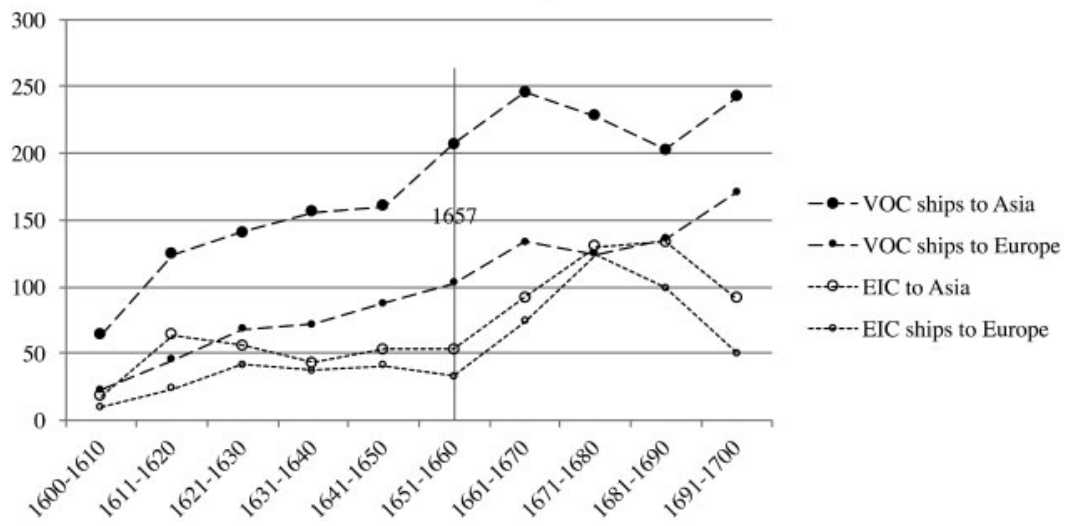

Figure A6. Ships, 1600-1700 (number of ships).

Source: van Dam (1927); Chaudhuri (1965; 1993); Bruijn et al. (1979-1987); Steensgaard (1982).

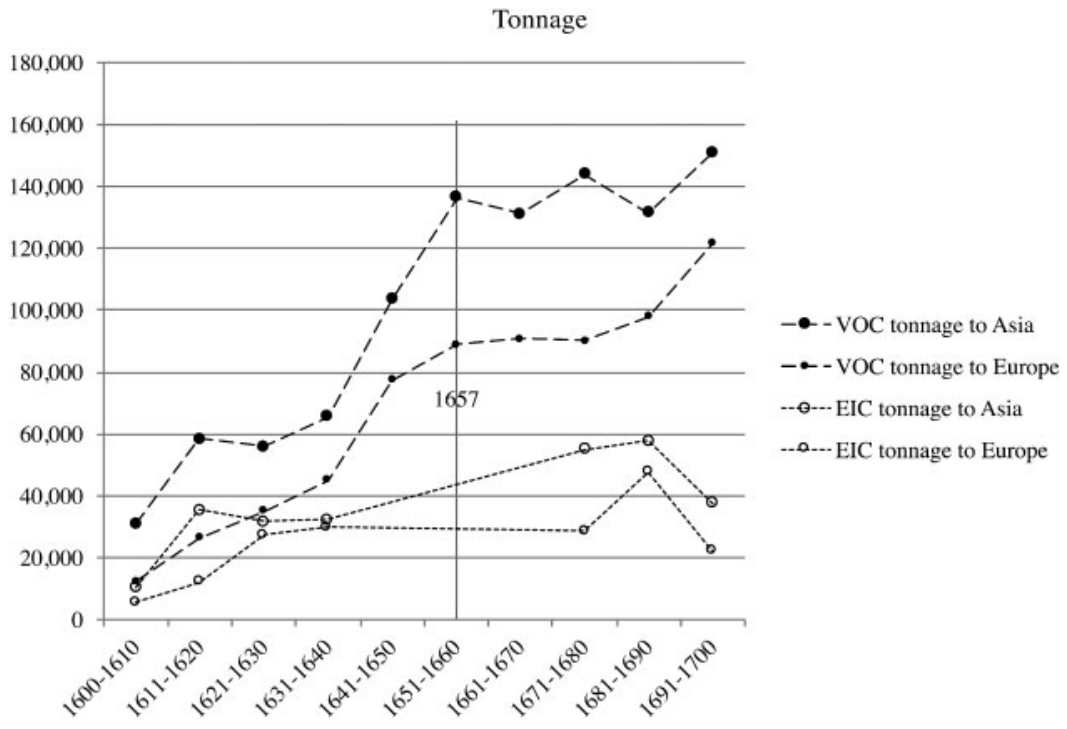

Figure A7. Tonnage, 1600-1700 (tons).

Source: van Dam (1927); Chaudhuri (1965; 1993); Bruijn et al. (1979-1987); Steensgaard (1982)

million guilders for four subsequent voyages and, following its good results, the Second Joint-Stock planned investments of 2 million guilders per year between 1617 and 1625. But that was not enough; the VOC had already moved to permanent capital and was able to invest on average 3.5 million guilders a year after 1617 , outspending and outgunning the 
EIC. The conquest of Bantam, the creation of Batavia in 1619 and the seizure of key ports enabled to build a local trading network, and intraAsian sales over time helped finance European purchases.

The following figures emphasize the effectiveness of the VOC organizational model with respect to ships (Figure A6), tonnage (Figure A7), and personnel (Figure A8) travelling to and from Asia, and the level of sales (Figure A9).

Personnel

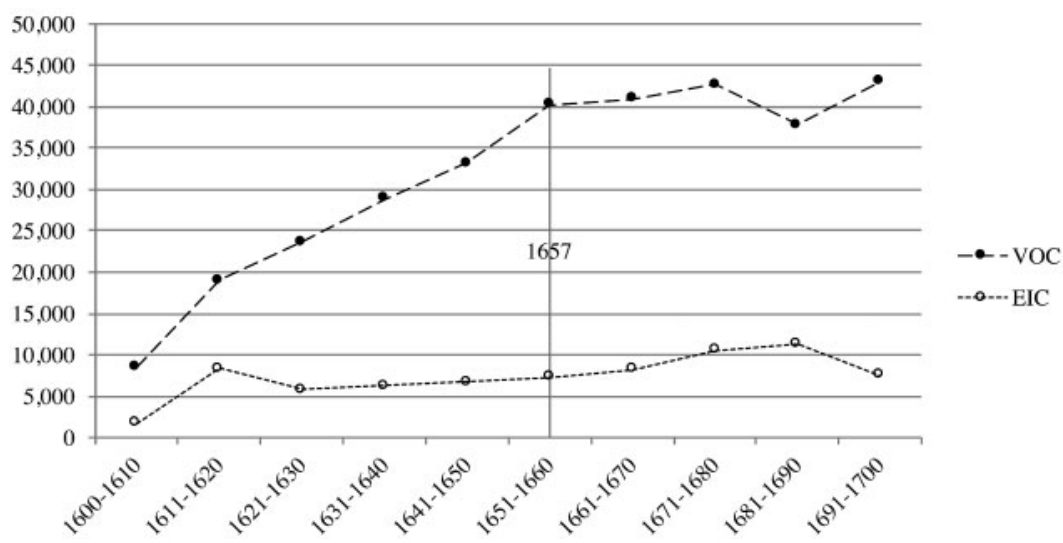

Figure A8. Personnel, 1600-1700 (number of people onboard).

Source: De Vries (2003: 69-70).

Sales

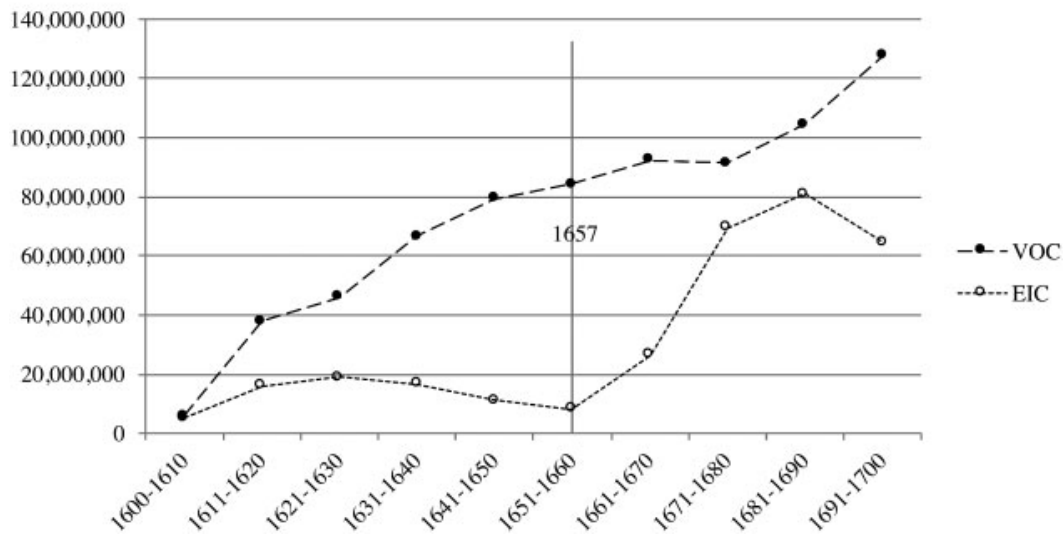

Figure A9. Sales, 1600-1700 (guilders).

Source: Chaudhuri (1978); de Korte (1984); Gelderblom et al. (2013: Online Appendix). 